\title{
Advances in Perinatology from the Clinical Research Centers
}

\author{
COMMITTEE: E. RICHARD STIEHM, CHAIRMAN, ${ }^{(245)}$ DARRYL C. DEVIVO, CO-CHAIRMAN, \\ ALFRED W. BRANN, JR., DELBERT A. FISHER, WILLIAM A. HODSON, MARIA I. NEW, \\ WILlIAM T. SHEARER, ROBERT J. SOKOL, PHILIP SUNSHINE, AND H. WILLIAM TAEUSCH
}

Division of Research Resources, National Institutes of Health, Bethesda, Maryland

\author{
Abbreviations \\ ADA, adenosine deaminase \\ CAH, congenital adrenal hyperplasia \\ CRCs, clinical research centers \\ HSV, herpes simplex virus \\ $\mathrm{L} / \mathrm{S}$, lecithin to sphingomyclin \\ NP, nucleoside phosphorylase \\ RDS, respiratory distress syndrome \\ HPRT, hypoxanthine-guanine phosphoribosyltransferase
}

\section{INTRODUCTION}

Both improved routine care of the newborn and management of newborn illness have dramatically reduced the infant mortality rate in the United States in the last $20 \mathrm{yr}$ (101). The single most important variable in infant survival is birth weight. Efforts to reduce mortality among low birth weight infants, most of them premature, have been extremely successful, and the USA now has one of the lowest birth weight specific neonatal mortality rates in the world (238). For example, in the early 1960s, only $10 \%$ of newborns weighing $500-1000 \mathrm{~g}$ survived, and only $50 \%$ of newborns weighing $1000-1500 \mathrm{~g}$ survived. In 1982 these survival rates are 40-50\% and $85-90 \%$, respectively! The outlook for survival without brain damage also has improved dramatically $(2,61)$.

These advances came after the realization that the premature infant could tolerate, and indeed required, medical intervention if is was to survive its early hostile world. Simultaneously, there was a major commitment of federal and private funds for improved care and research regarding pregnant women and their newborn infants. The 100 Clinical Research Centers (now reduced to 71 centers) scattered throughout the USA have made a major contribution to this research effort. Most of these centers have research programs with a pediatric or obstetric focus; indeed, several centers are located in Children's Hospitals, one is focused on perinatal medicine and one is located exclusively in a newborn nursery.

This report, prepared by a committee of nine pediatricians and one obstetrician, identified major advances in perinatal medicine that have been wholly or in some measure initiated and carried out in National Institutes of Health sponsored Clinical Research Centers. Areas of perinatology covered include intensive care, nutrition, prenatal and obstetric management, respiratory distress syndrome, metabolic disorders, endocrine disorders, cardiovascular disorders, hematologic disorders, neurologic disorders, and immunologic and infectious disorders (51, $73,123)$.

\section{NEONATAL INTENSIVE CARE}

Hospital-based nurseries for premature babies were first developed in the United States in the 1920s, but it was not until the late 1940s that research on their tiny occupants was initiated. Despite some therapeutic advances such as the use of antibiotics in the treatment of septic infants, there was little, if any, improvement in neonatal mortality rates between the mid-1940s and the early 1960s. Indeed, therapeutic advances were often overshadowed by therapeutic misadventures (73). For example, the use of high oxygen levels for the treatment of small babies with apnea led to the subsequent development of retrolental fibroplasia. When oxygen was recognized as a cause of retrolental fibroplasia, curtailment of oxygen therapy led to an increased incidence of neurologic sequelae. Although many antibiotics were effective, the prophylactic use of the sulfonamides led to an increased incidence of kernicterus; therapeutic doses of chloramphenicol in prematures led to cardiovascular collapse and shock, the "gray baby syndrome." Vitamin K prevented hemorrhagic disease of the newborn, but its overzealous use led to hyperbilirubinemia and kernicterus.

These results and early observations $(51,123)$ that as many as $60 \%$ of low birth weight infants had neurologic or intellectual impairment led many physicians to question any attempt to improve the survival of low birth weight infants.

In the early and mid-1960s, an abrupt improvement in perinatal mortality occurred, which has further accelerated in the 1970s and 1980s. This improved infant survival can, in large part, be attributed to the development of intensive care nurseries, including clinical research centers. In these centers, careful and meticulous clinical investigation on critically ill infants has markedly improved neurologic, intellectual, and developmental outcome. Much of this improvement is a result of improved fetal monitoring and care. For example, study of temperature control and the metabolic effects of temperature alterations led to the development and improvement of infant warmers $(45,46,171)$. The development of apnea monitors (42) and devices to monitor heart rate patterns and blood pressure (97) have also markedly improved patient care and survival. Many of these research advances are now part of routine intensive care of infants throughout the US and the world.

CRCs have also contributed significantly to medical education. A cadre of nurses were trained in these facilities and these nurses not only provided infant care but were actively involved in investigative endeavors, including the use of complicated monitoring equipment. These nurses have assumed positions of leadership in intensive care nurseries throughout the USA. The CRCs are principally responsible for the concept that nurses are integral members of the research team.

Similarly, because the care of the infants and clinical research 
are so closely combined, countless medical students and house officers received their first, and often their only exposure to clinical research during their rotation on the nursery services. Many students have had their curiosity heightened and been stimulated to enter a career in investigative medicine. This factor is a frequently overlooked, but crucial contribution of the clinical research centers.

\section{NUTRITION}

Total parenteral nutrition. Many prematurely born infants have incomplete development of their gastrointestinal systems and cannot tolerate oral feedings. Investigators at the University of Pennsylvania first investigated the feasibility of supplying all nutrients on a long-term basis by the intravenous route, a procedure now termed total parenteral nutrition (55). These studies, initially carried out in Beagle puppies, were soon applied to humans. One of the first pediatric applications of total parenteral nutrition was in an infant with a markedly shortened intestine who was studied in a clinical research center (237). The use of total parenteral nutrition in neonates with surgical disorders soon led to its use in infants of very low birth weight. This was aided by the development of catheters constructed of relatively inert materials which caused minimal vascular dysfunction and were adaptable for infant use (23). CRC investigators soon recognized a number of biochemical and metabolic problems associated with total parenteral nutrition. These included hyperosmolarity, acidosis, hyperammonemia, azotemia and impaired glucose utilization. Subsequently, alterations in the type and content of solutions were developed to circumvent these complications (1, $54,57,91)$. The combined use of enteral and parenteral nutrition allowed many small infants to gain weight, resist infection, and adapt to their extrauterine environment.

The nutritional requirements of these low birth weight infants have also been investigated (6). It was demonstrated that these infants' ability to handle nutrients was vastly different than in older infants; moreover, their endocrine responses were considerably different $(217,235)$.

Use of human milk. Another major advance in the nutrition of low birth weight infants was the use of human milk in intensive care nurseries. Previous studies suggested that human milk did not contain adequate amounts of protein to insure optimal growth of immature infants as compared with proprietary formulae that contained $3-4 \%$ protein. Drs. Gaull, Raiha and their CRC co-workers clearly demonstrated that preterm infants could grow and develop normally when fed human milk $(66,179,180$, 181). They also showed that breast milk contains certain amino acids essential for preterm infants $(67,182,183)$. These investigators, working with infants and children with defects of sulfated amino acid metabolism, noted that preterm infants have decreased activity of hepatic cystathionase (222), and that breast milk has greater concentrations of cystine than proprietary formulae. They speculated that human milk has distinct advantages for low birth weight infants.

Human milk was also found to have a number of host resistance factors that potentially could protect the preterm infants from various intestinal disorders such as necrotizing entercolitis (70). The concern was that these factors would be inactivated if the breast milk was processed, but investigators at the Stanford $\mathrm{CRC}$ demonstrated that pasteurization, lyophylization and freezing had little, if any, effect on the concentration and activity of these factors, including secretory IgA immunoglobulin (119).

Gastroesophageal reflux. Gastroesophageal reflux may lead to a variety of problems in newborns and young infants including feeding difficulties, failure to thrive, and respiratory problems. Studies in the Stanford CRC increased the awareness of US physicians in the USA of this problem $(63,64)$ and contributed importantly to the understanding of its pathogenesis, diagnosis, and treatment $(22,75,76,90)$. Techniques to monitor esophageal $\mathrm{pH}$ for a $24-\mathrm{h}$ period have elucidated the relationship between gastroesophageal reflux and pulmonary abnormalities $(47,170)$.
Infants of diabetic mothers. Another major advance has been the improved management of infants of diabetic mothers; these infants often are macrosomic, polycythemic, and have severe respiratory distress. Early identification of women at risk (211), improved dietary and hormonal treatment during pregnancy, and allowing these mothers to proceed to term without early induction has improved infant survival. Techniques to evaluate these infants in utero and to recognize early complications have been developed (149, 150, 219).

Mineral metabolism in newborns. Infants fed cows' milk formula rather than breast milk receive a large phosphate load. The parathyroid response to this phosphate load may drive calcium from the blood into the bone and other tissues and cause hypocalcemia and tetany. Although U.S. formulae have been "humanized" to reduce the phosphorus content, tetany still occurs. At the Cincinnati Children's Hospital CRC, five full term infants with tetany who had been fed a standard proprietary formula were studied (230). Parathyroid hormone levels were high and remained elevated during the time that the formula was continued. Thereafter, the blood calcium returned to normal or even high levels, indicating fluctuation of parathyroid secretion in response to dietary alterations.

Additional studies at Cincinnati have shown low levels of vitamin $\mathrm{D}$ metabolites in breast fed infants, loss of bone mineral, and a predilection for rickets without vitamin D supplementation $(71,218)$.

Magnesium deficiency also was noted to affect calcium regulation through diminished production of parathyroid hormone (49). Newborns with magnesium deficiency given magnesium were shown to respond appropriately with increased production of parathyroid hormone.

\section{PRENATAL AND OBSTETRIC MANAGEMENT}

Introduction. Use of amniocentesis as a management tool for $\mathrm{Rh}$ isoimmunization in the early 1960 s led to the concept that the fetus is a patient, albeit an inaccessible one, and that birth is not so much a beginning as a transition from intra- to extrauterine existence. If the fetus is viewed as a patient, then increased diagnostic information has to be obtained. This led to improved areas of fetal monitoring, better description of normal fetal growth and development, better assessment of pregnancy duration and fetal nutrition, and improved diagnosis of abnormal fetal conditions including exposures to substances used by or administered to the mother.

CRC investigators have made major contributions to advances in prenatal assessment over the past $20 \mathrm{yr}$. In this section, several long term efforts that have led to improved materno-fetal care are discussed.

Fetal monitoring during labor. CRC investigators have contributed to the development and assessment of electronic and biochemical monitoring of the fetus during labor. CRC investigators were among the first to document the relationship of abnormal fetal heart rate patterns to fetal and maternal acid/ base balance (96). CRC investigators at Cleveland related abnormal fetal heart rate patterns during labor to both lowered fetal scalp blood $\mathrm{pH}$ (acidosis) and neonatal nervous system depression, delineated the fetal heart rate changes associated with umbilical cord entanglement and prolapse, and developed a practical classification of fetal heart rate abnormalities $(151,152)$. They also pioneered the development of "wireless" fetal monitoring (telemetry) $(137,138,139,196)$.

$\mathrm{CRC}$ research has focused on complications of fetal monitoring and limitations of fetal heart rate as an indicator of fetal stress (212). The application of computer technology has permitted improved bedside clinical risk assessment $(32,190)$. These computer programs can be used for 1 ) medical/obstetric risk identification and prediction of perinatal outcome (209), 2) perinatal data management and clinical report generation (31), 3 ) diagnosis and management of normal and abnormal labor $(205,206,210), 4)$ evaluation of uterine contractions $(27,28)$, 
and 5 ) detection of abnormal fetal heart rate deceleration patterns (29).

There has been considerable public and professional concern about the high cesarean birth rate associated with changes in obstetric management. A 3-fold increase in the use of abdominal delivery and changes in indicators for cesarean section over the past decade were documented (19). A CRC study was the first to support a National Institutes of Health Task Force conclusion that a high cesarean birth rate is not necessitated by abnormal labor progress. Using a CRC computerized database, it was found that at the CRC institution only one in four labors complicated by severe abnormality were delivered by cesarean section, compared with two of three nationally (208); moreover, this was achieved without a high operative forceps rate and with excellent infant outcome (20).

Prenatal development of the brain. The potential contribution of prenatal events to abnormal neurobehavioral development, e.g., cerebral palsy and mental retardation, has been recognized since the nineteenth century. Until $20 \mathrm{yr}$ ago, retrospective review of the histories of damaged children and adults often disclosed complicated perinatal courses, particularly birth trauma, i.e., difficult labor and delivery. Fetal brain wave (EEG) recordings made during labor as an indicator of brain damage were undertaken by CRC investigators (33). The recording before birth wave patterns comparable to those of the neonate indicated that the brain does not "turn on," so to speak, at birth (33). Instead, these studies indicate that central nervous system function develops throughout the prenatal period and can be disrupted before labor, resulting in aberrant long-term neurodevelopment $(34,35)$. In one study (207), a specific pattern of abnormal brain wave activity (hypsarrhythmia), known to be associated with severe abnormality in the young child, was detected early in labor, clearly documenting brain damage in the antepartum period. These observations point to the need for further evaluation of central nervous system development in relation to brain damage.

CRC supported studies by Timor-Tritsch et al. (228), evaluated fetal movements with strain gauges on the maternal abdomen as a prelabor indicator of brain development. Several types of fetal movement were described, classified, and correlated with fetal heart rate changes (227), and fetal breathing movements (229). During extended periods of study, the fetus was noted to have alternating active and quiet periods of behavior (226). These movements were classified into several recognizable patterns, reflecting various levels of brain activity as they develop before birth.

Obstetric analgesia. Despite the widespread use of obstetric anesthesia, little is known about the metabolism of analgesic drugs by the mother, fetus, and neonate. CRC investigators at Cleveland have measured trace levels of drugs and their metabolites with gas chromatography/mass spectrometry in order to investigate how these agents affect the infant. Studies on meperidine, lidocaine, and 2-chloroprocaine, three drugs most commonly used for pain relief during delivery, are underway.

Meperidine. This drug causes respiratory depression in the newborn, even if given to the mother in low doses, particularly if given several hours before instead of close to delivery. It was hypothesized that the respiratory depressent effect was due to the formation of a toxic metabolite, normeperidine. Using sensitive analytic techniques, CRC investigators demonstrated the metabolic conversion of meperidine to normeperidine, and the presence of meperidine and normeperidine in blood and urine of mothers and urine of neonates $(107,108)$. The placental passage of normeperidine and the increased amounts of normeperidine in cord blood with time (105) explained its adverse effects on the neonate when the drug was given $3 \mathrm{~h}$ before delivery compared with its effect when given within $1 \mathrm{~h}$ of delivery.

Lidocaine. The lidocaine metabolites monoethylglycinexylidide and glycinexylidide act similarly to the parent compound. Although it was known that the use of lidocaine can adversely affect neonatal outcome, its metabolism in pregnancy and neonates had not been adequately studied. A CRC study (104) showed that lidocaine levels in maternal plasma are much higher than in fetal plasma at delivery, but that the monoethylglycinexylidide and glycinexylidide levels in maternal and fetal plasma are similar, and occasionally higher in fetal than in maternal plasma, indicating their metabolic origin is to some degree from the fetus (104).

Chloroprocaine. The metabolism of chloroprocaine by plasma enzymes in the mother is so rapid that it had not been assayed previously in maternal plasma nor thought to cross the placenta. $\mathrm{CRC}$ investigators utilized sensitive techniques to demonstrate that placental transfer of chloroprocaine does occur (106). Low levels of blood enzymes present in women with term pregnancies are adequate to metabolize most, but not all of the chloroprocaine diffusing into the blood; thus, some of the drug crosses the placenta. Chloroprocaine administration can lower maternal levels of pseudocholinesterase and have a potential adverse effect if the muscle relaxant succinylcholine is subsequently administered.

Fetal exposures: alcohol abuse in pregnancy. The first report that maternal alcohol abuse was associated with fetal damage appeared in 1973. Shortly thereafter, a study of the fetal consequences of maternal alcohol abuse was begun in a CRC, cosponsored by the National Institute on Alcohol Abuse and Alcoholism. The first large American prospective study was performed using the computerized perinatal files of the Cleveland Perinatal CRC (204). This study of over 12,000 consecutive deliveries first identified a 2-fold risk of spontaneous abortion among the heaviest drinking $2 \%$ of pregnant women. Increased risks for congenital anomalies, intrauterine growth retardation, and full fetal alcohol syndrome were also identified.

\section{RESPIRATORY DISTRESS SYNDROME}

Introduction. A major cause of death among premature infants is RDS, also termed hyaline membrane disease. The more immature the infant, the greater the risk of developing the disease and the more severe the disease. When President Kennedy's newborn infant died of RDS in 1963, there was a public outcry for studies on the cause and treatment of this disorder.

Studies had already been initiated that demonstrated that the lung of infants had decreased activity of surface tension reducing material (surfactant) compared with term infants (9). Accordingly, RDS could best be viewed as a developmental and biochemical deficiency of surfactant (68). Several CRCs were involved in studies of surfactant concentrations in amniotic fluid of pregnant women to predict when the fetus was sufficiently mature to survive in the extrauterine environment $(77,109)$. Methods were then developed to treat RDS successfully, including ventilator support, continuous distending airways pressure, high frequency $(300 / \mathrm{min})$ ventilation, and postnatal administration of artificial surfactants $(43,44,65,89,111,125,203,225)$.

Physiology of RDS. The physiology of RDS has been investigated by CRC-supported programs. One of the most perplexing aspects of RDS in the 1960 s was the interplay of surfactant deficiency and shunts through the patent ductus arteriosus. It was known that in immature hypoxic newborns with RDS the ductus arteriosus remained patent for an abnormal length of time. Three schools of thought existed $l$ ) that left-to-right shunts flooded the lungs and contributed to RDS symptomatology, 2) that right-to-left flow occurring through the ductus contributed to the hypoxemia of RDS, and 3) that surfactant deficiency in RDS was the main problem and that no flow occurred through the patent ductus. A CRC-supported study at Stanford (38) helped to identify subgroups of infants that exemplified all three situations depending on gestational and postnatal age. More mature infants with RDS, often with hypoxia, frequently manifest persistent fetal circulation (failure of ductal closure) with a right-to-left ductus shunt; such infants may improve with pulmonary vascular vasodilator therapy.

Biochemistry of RDS. Basic studies of the ontogeny of fetal hormones and the maturation of respiratory control centers has 
led to new approaches in the prevention of RDS and sudden infant death in RDS survivors with chronic lung disease. Biochemical and physiologic studies indicate that several surface active compounds, particularly dipalmitoyl lecithin and phosphatidylglycerol, stabilize the alveoli of the lung so that normal gas exchange can occur. The absence of these phospholipids, collectively termed surfactant, is the single most significant cause of RDS. Early CRC-supported research focused on fetal lipid metabolism, specifically that of fatty acids. The most significant of these fatty acids is palmitic acid, a 16-carbon saturated molecule. Dipalmitoyl lecithin, which contains two palmitic acids, is the most important component of surfactant. Ten years ago it was believed that the 28-35-wk gestation fetus could not form dipalmitoyl lecithin, but formed a lecithin containing a different fatty acid, myristic acid, an inferior surface active agent. CRC investigators, using radioactive isotopes in tissue culture, showed that fetuses can form palmitic acid as early as 28 wk gestation $(194,197,242)$. A crucial finding was that palmitic acid could be synthesized by the fetus from the two-carbon building block, acetate.

Amniocentesis. Gluck, et al., (69) reported in 1971 a breakthrough finding that levels of amniotic fluid surfactant reflected levels of surfactant in the fetal lung, enabling amniotic fluid analysis to be used to predict RDS. Perinatal CRC investigators in Cleveland confirmed this work within a year of the initial paper (136). The accuracy of the amniotic L/S ratio in predicting RDS in the newborn was confirmed in a clinical study performed in a CRC. In a series of studies published from 1972 through 1974, these same investigators suggested that the $\mathrm{L} / \mathrm{S}$ ratio has a high frequency of false negative results $(135,195)$. Specifically, it was suggested that when the $\mathrm{L} / \mathrm{S}$ ratio was negative, as high as $90 \%$ of patients did not develop RDS. Although this finding was initially questioned, it has since been confirmed (110).

Research aimed at improving the clinical usefulness of amniotic fluid phospholipid determinations has continued in CRCs. For example, Kuhnert, el al. (109) developed an improved technique for determining the $\mathrm{L} / \mathrm{S}$ ratio in amniotic fluid. The clinical importance of this new technique is that it is simpler and faster to perform than the older method, making it possible to obtain immediate results for clinical management even on an emergency basis. Also, the new technique has a lower false negative rate, leading to improved prediction accuracy. Initially studied in 229 CRC patients, the new rapid method was confirmed to be clinically useful in more than 1000 patients.

Accurate prediction of pulmonary functional maturity is now a key component of perinatal management, particularly in pregnancies complicated by chronic hypertension, preeclampsia, $\mathrm{Rh}$ isoimmunization, or diabetes mellitus. In the presence of these problems, early delivery can improve pregnancy outcome. Using amniotic fluid phospholipid determinations, the risk for RDS can often be diminished.

Studies of amniotic fluid phospholipids in fetal disorders continue to be supported by the CRC program. These include an improved two-dimensional technique for determining phospholipids, and the use of phosphatidylglycerol levels to identify fetuses with intrauterine growth retardation, lung immaturity, and transient tachypnea of the newborn (72).

Treatment of $R D S$. In the early mid-1960s, it became evident that although infants with RDS were given appropriate medical and nursing care, they would often develop respiratory failure and die. With the development of endotracheal intubation and the use of mechanical ventilation. many of these infants began to survive $(43,203,225)$. The development of many of these new ventilation techniques took place in CRCs. Initially, it was cumbersome to ventilate critically ill infants, but as newer appliances were introduced, more infants with RDS survived $(44,92$. $111,125)$. Although few controlled prospective studies were carricd out evaluating whether or not ventilators improved survival of low birth weight infants, it rapidly became evident that if one could identify the infant at risk and assign a scoring system to determine the biochemical and physiologic abnormalities, one could correct these by the appropriate use of mechanical ventilation $(43,92)$. Initially, mechanical ventilation was used primarily for the support of term or large preterm infants, but as the techniques and knowledge of utilization of ventilators improved, smaller and smaller babies were ventilated successfully.

Bronchopulmonary dysplasia. The use of mechanical ventilation in critically ill infants, although enhancing survival, contributed to the development of a new illness, bronchopulmonary dysplasia, first recognized at the Stanford CRC $(58,145,146$, 147). Bronchopulmonary dysplasia develops only in infants who receive mechanical ventilation and occurs in as many as $70 \%$ of such infants. The recognition of the danger of high oxygen and ventilator support led to alterations in ventilator management, which have subsequently reduced the incidence of bronchopulmonary dysplasia $(58,92,203)$.

Other investigators feared that even though there was an increased rate of survival with mechanical ventilation, these infants would have moderate to severe neurologic handicaps. Careful investigations in CRCs and other institutions demonstrated clearly that most infants receiving ventilatory support were neurologically undamaged. Long-term follow-up of survivors of mechanical ventilation indicated that less than $10 \%$ of these infants had survived with significant handicaps, and another $5 \%$ had mild to moderate abnormalities (92). These results were much better than results when the infants were managed in adult intensive care units.

Development of intensive care units. The realization that RDS as well as other respiratory disease could be managed successfuily led to the development of intensive care nurseries throughout the U.S. The development of newer ventilators and the improved knowledge of respiratory physiology have grearly improved the management of low birth weight infants.

\section{CARDIOVASCULAR DISORDERS}

Introduction. Significant advances in the medical and surgical treatment of cardiovascular disorders of newborn infants have occurred over the past 10-15 yr. Medical aspects include improved diagnostic techniques such as Doppler and echocardiographic assessment of congenital cardiac defects and pharmacologic treatment of heart failure, pulmonary vasoconstriction, and patent ductus arteriosus.

Medical management. CRC investigators at Yale first described blood gas and acid-base disorders that included respiratory failure in infants with congestive heart failure (224). Decreased serum sodium and chloride concentrations also occurred, adversely influencing the response to digitalis and diuretics.

Engle et al. (81) at Cornell found that infants tolerate a higher serum digitoxin concentration than adults without evidence of toxicity and most likely require higher serum levels for therapeutic effects. These studies showed that assessment of serum digitoxin levels provides a guide to the adequacy of digitalization and recognition of toxicity. This group also was among the first to establish safe and effective dosage of furosemide in the treatment of edema secondary to cardiac and renal disease in infants (60). This drug is now used widely in infant intensive care units.

Barr et al. (14) at Alabama assessed blood volume in critically ill newborn infants. They found a poor correlation between blood volume measured with tagged albumin and blood pressure, injecting an element of caution into the once common practice of plasma volume expansion in infants with low blood pressure.

Studies in the neonatal CRC at Stanford have explored the use of tolazoline in infants with refractory hypoxemia due to neonatal pulmonary disease or persistent pulmonary hypertension (82. 220). Many infants demonstrated improved gas exchange, presumably due to the increased pulmonary blood flow secondary to tolazoline. These investigations have stimulated additional studies on myocardial function in persistent fetal circulation and the effects of tolazoline on cardiac output and cardiovascular hemodynamics.

Cardiovascular surgery. Correction of many previously un- 
treatable congenital heart lesions is now possible by open heart surgery during the neonatal period. Studies of infants with congenital heart disease conducted in the University of Chicago CRC by Matthew et al $(41,129)$ have provided new information on two common types of congenital heart disease in infants: total anomolous pulmonary venous return and common atrioventricular canal. The effects of surgical repair on total anomolous pulmonary venous return with and without significant pulmonary venous obstruction have been described. Ventricular volumes, left ventricle ejection times, and left atrial function assessed before and after surgery indicate normalization of cardiac function and beneficial effects independent of preoperative left ventricular size.

\section{HEMATOLOGIC DISORDERS}

Prenatal diagnosis. The prenatal diagnosis of several genetic hematologic disorders has evolved rapidly over the past decade. Currently three techniques are employed: I) amniocentesis, permitting the detection of over 40 biochemical genetic disorders through chromosomal abnormalities of fetal cells obtained from amniotic fluid; 2) ultrasound, allowing non-invasive detection of morphologic abnormalities of the fetus; and 3) fetoscopy, involving assessment of fetal tissue, usually placental blood, obtained during the second trimester of pregnancy. Hobbins et al. (48, 50, $86,124)$ at the Yale CRC have had extensive experience in the fetoscopic diagnosis of hemoglobinopathies and other blood disorders. Through endoscopic visualization of fetal placental vessels abetted by ultrasound visualization, samples of fetal blood are obtained through a 26 gauge needle. Sampling of fetal red blood cells has enabled diagnosis of several hemoglobinopathies, such as thalassemia major and sickle cell anemia.

The type of hemoglobin that appears during fetal development is a function of the site of synthesis as well as the gestational age of the fetus. Alpha-, $\beta$ - and $\gamma$-chain globin components of fetal red blood cells are quantified by carboxymethyl-cellulose radiochromatograms to detect decreased $\beta$-chain synthesis. Patients who are heterozygous carriers of thalassemia have a $25 \%$ chance of having a homozygous child who will manifest the severest form of the disease; therefore, these procedures provide valuable information regarding the conduct of continued pregnancy or postnatal diagnosis and treatment. Similarly, the use of fetoscopy permits the prenatal diagnosis of inherited coagulation disorders including Hemophilia A, Hemophilia B (Christmas disease), and homozygous Von Willebrands disease. Immunodeficiencies such as combined immunodeficiency, Wiskott-Aldrich syndrome, chronic granulomatous disease, and $\mathrm{X}$-linked agammaglobulinemia are also potentially diagnosable (48).

Erythrocvtic enzyme studies. Studies of red blood cell metabolism of fetal and newborn infants have been facilitated through the CRC at the University of Pennsylvania and the State University of New York at Syracuse. 2.3-Diphosphoglycerate is one of the principal organic phosphates of the red cell that combines reversibly with deoxyhemoglobin, decreasing the affinity of hemoglobin for oxygen. After the discovery in 1968 of rapid increase in 2,3-diphosphoglycerate content of adult erythrocytes in response to hypoxia, Oski et al. (156) studied infants with congenital heart disease and pulmonary insufficiency and found increased 2,3-diphosphogylycerate levels. They subsequently found that the fetal hemoglobin of red blood cells of newborn infants showed no 2,3-diphosphoglycerate response to hypoxemia. These differences in the hemoglobin dissociation curve between fetal and adult hemoglobin explain many metabolic pecularities of fetal red blood cells.

Other studies by Komazawa et al. at Syracuse (100) have examined red cell glucose phosphate isomerase and glyceraldehyde-3-phosphate dehydrogenase activities to determine their possible role in hemolysis and transient hyperbilirubinemia in newborn infants. They found no relationship between the levels of these enzymes and neonatal jaundice. Other studies have demonstrated a lower glutathione peroxidase level in newborn red blood cells, compared with adult red blood cells, and elevated pentose phosphate pathway activity in the red cells of premature infants $(154,233)$. Other CRC studies provided preliminary evidence that determination of minor hemoglobin ratios $\left[\frac{\left(F_{1}+A_{1 C}\right)}{\left(F_{1}+A_{1 C}+A\right)}\right]$ show an excellent linear correlation with gestational age (172).

Vitamin E deficiency. Oski et al. (155) were the first to show that vitamin $E$ deficiency could cause hemolytic anemia in the premature infant (158). Infants treated with and without vitamin E supplements were studied serially over several weeks. Vitamin $E$ administration was found to prevent or ameliorate hemolysis and subsequent anemia. Prophylactic vitamin E now is standard treatment for all low birthweight infants.

Neonatal blood donor studies. Studies conducted at the Stanford neonatal CRC have examined the immediate and longrange effectiveness of a walking-donor blood transfusion program for a neonatal ICU (169). Heparinization of blood led to no coagulation problems in the neonate and there was no increased risk of transmission of $\mathrm{HbsAg}$; however, the incidence of cytomegalovirus infection of recipients was increased slightly over control infants. Such a walking-donor program can provide fresh blood in small aliquots on short notice for neonatal special care units without immediate access to a blood bank; however, some risks exist which require further study.

\section{METABOLIC DISORDERS}

Mucopolvsaccharidoses. Studies conducted in CRCs have helped elucidate the basic defects associated with a number of neonatal disorders leading to early or progressive brain damage. Among these are the syndromes referred to as the mucopolysaccharidoses. These disorders involve the widespread accumulation of polymers of sugar-like compounds (glycosaminoglycans) in tissues. The tissues involved include brain, skeleton, and connective tissues so that growth and mental development usually are deficient.

Elucidation of the metabolic defects in the mucopolysaccharidoses became jossible with the observation of Fratantoni. Hall. and Neufeld at the National Institutes of Health that cultured fibroblasts incorporate radioactive $\left[{ }^{35} \mathrm{~S}\right]$ sulfate almost exclusively into sulfated glycosaminoglycans. Studying fibroblasts of patients with mucopolysaccharidoses, these investigators showed that the accumulation of glycosaminoglycans was due not to excessive production but to decreased degradation. During the 1970s, work proceeded apace in the laboratories of Neufeld at the National Institutes of Health and Dorfman in the Chicago CRC to characterize the degradative and molecular defects in some eight types of mucopolysaccharidoses.

Dorfman's group utilized the CRC at the University of Chicago for patient evaluation. The diagnoses were established and the tissues and urine samples were used for in vitro studies of mucopolysaccaride excretion and fibroblast glycosaminoglycan metabolism. Dorfman's group, nearly simultaneously with Neufeld, described an $\alpha$-iduronidase deficiency in Hurler's Syndrome and an $\alpha$-iduronosulfate sulfatase deficiency in Hunter's Syndrome $(128,202)$. This group (126) described a deficiency of $N$ acetyl galactosamine-4-sulfate sulfatase in the Moroteaux-Lamy Syndrome. The defect in Morquio's Syndrome (and $\mathrm{N}$-acetyl hexosamine sulfate sulfatase) was described by Matalon et al. from Dorfman's laboratory (127). In later studies, the specificity of this enzyme for $N$-acetyl galactosamine-6-sulfate was reported (88). These now classic studies have paved the way for studies of effective treatment of these devastating disorders.

Urea cycle disorders. Much of the critical work on infants with urea cycle enzymopathies was accomplished in CRCs. These disorders lead to severe metabolic disorder and often death early in life. The first patient recognized with an abnormality of urea biosynthesis was reported by Allan and co-workers in 1958 when they described a patient with argininosuccinic aciduria. Since that time, patients with abnormalities of each of the enzymes 
involved in urea biosynthesis have been recognized. Studies from the Yale CRC described newborn males with hyperammonemia due to a defect of orithine transcarbamylase (26), demonstrating that lethal forms of these defects could occur in the neontal period. The same investigators also elucidated an X-linked inheritance in ornithine transcarbamylase (201). Subsequent studies from the Stanford CRC demonstrated that carriers of ornithine transcarbamylase deficiency could be identified readily by the presence of elevated concentrations of urinary orotic acid after ingestion of a protein load (83).

Batshaw et al. (15) from the Johns Hopkins Pediatric CRC noted that defects of urea biosynthesis are not rare, and may be encountered as frequently as 1 in 2500 live births. Initially, they treated these infants and children with nitrogen-free ketoanalogues of essential amino acids because these patients had a great deal of difficulty with repeated episodes of hyperammonemia. The mortality rate in these patients was still extremely high. Recently, these investigators evolved a new approach to therapy for these patients (24). An increased intake of arginine (except in patients with arginase deficiency) and sodium benzoate enhances the excretion of hippuric acid and lessens the risk of hyperammonemia in these patients. In addition, phenylacetic acid has also been used because this substance acetylates glutamine to form phenylacetyl glutamate, which is also readily excreted in urine. This treatment offers a promising therapeutic approach for infants, who heretofore had rapidly fatal courses.

Purine metabolism abnormalities. CRC studies also characterized several inborn errors of purine and uric acid metabolism. The purines adenine and guanine form two of the four basic nucleotide units of DNA and RNA, respectively. Derived either from the diet or synthesized from smaller molecules, they are metabolized to xanthine and excreted as uric acid. ixcessive accumulation of uric acid leads to hyperuricemia with or without gout. There is an alternative pathway for formation of purine nucleotides from preformed purines, and this pathway has been considered, until recently, to be merely a salvage mechanism. In 1964, Lesch and Nyhan (114) studied two brothers in the Johns Hopkins CRC who had mental retardation, choreoathetosis, and self mutilation in association with high blood uric acid levels and increased uric acid excretion. These cases, the first of several heritable disorders of purine metabolism now characterized, subsequently were shown to have a deficiency of the enzyme HPRT. Most of the patients with phenotypic Lesch-Nyhan disease have near absence of HPRT activity. Over 150 cases have been documented; the pedigrees of all patients have shown an X-linked inheritance pattern $(79,114)$.

More recent studies have documented the existence of patients with less severe HPRT deficiency and corresponding attenuation of their clinical expression $(10,223)$. Description of the LeschNyhan syndrome has led to extensive research clarifying the importance of the purine nucleotide cycle in various tissues, including brain, and led to the characterization of a number of inborn defects of uric acid metabolism with mental retardation. Although these disorders are not presently treated effectively, it is now possible to provide genetic counseling and intrauterine diagnosis.

Amino acidurias. Studies in several CRCs have contributed to the understanding of inherited defects of amino acid metabolism, which often lead to early metabolic abnormalities and brain damage. Organic acidurias which result in profound acidosis and early death were included in these studies. Rosenberg et al. (191) and Barness and Morrow (13) were among those who characterized the first of these disorders, methylmalonic aciduria. Rosenberg et al. (191) demonstrated that a defect in conversion of methylmalonic $\mathrm{CoA}$ to succinyl $\mathrm{COA}$ produced the marked acidosis (134). Morrow and co-workers demonstrated that the defect was due to a deficiency of the enzyme methylmalonyl CoA mutase and that two forms of enzyme deficiency occurred: 1) an essential absence of the enzyme and 2) a defect in the vitamin $\mathrm{B}_{12}$ coenzyme activator. It has been shown that administration of vitamin $B_{12}$ would improve some infants with the coenzyme abnormality (191). Six variants of the disease have now been described.

Phenylketonuria is a well-known disorder of amino acid metabolism for which newborn screening has been legislated throughout the United States and other parts of the world. Early diagnosis and institution of a low phenylalanine diet ameliorates the brain damage in phenylketonuria. It has long been observed that a few children develop neurologic damage in spite of adequate dietary control of blood phenylalanine levels, but the explanation has not been apparent.

In the first major advance in this important area in some 15 yr, Kaufman et al. $(94,95)$ studying patients with dietary resistant phenylketonuria, described two variants of the disease. In both variants, phenylalanine hydroxylase (the usually deficient enzyme) levels were normal; however, in one variant, there was a profound deficiency of dihydropteridine reductase and in the other, there was a defect of tetrahydrobiopterin. Both substances are necessary for normal phenylalanine hydroxylase cofactor activity, and deficiency of either factor produces metabolic defects not correlated by normalizing blood phenylalanine levels. Appropriate therapy for the variant cases now is under investigation.

Carbohydrate metabolism. Several important advances in carbohydrate metabolism have occurred in CRCs. One of these was the demonstration that careful control of diabetes mellitus in pregnant women during the last trimester of pregnancy minimizes the large variations in maternal blood sugar concentrations $(80,131,189)$. Development of devices to frequently measure blood sugar and adjust insulin infusion rates to maintain near normal blood glucose levels throughout the day has led to the concept that careful control of maternal diabetes decreases the complications in the neonate. Improved monitoring of women during pregnancy has identified women at risk, and led to early and appropriate dietary and insulin treatment. Allowing these mothers to proceed to term has resulted in improved newborn survival. Techniques to evaluate these babies in utero and recognize early complications have also been developed on CRCs $(149,150,211,220)$.

The maturity of the blood sugar control mechanisms of small premature infants has been studied in a CRC. Dweck and colleagues (57) documented glucose intolerance in very low birth weight infants by demonstrating a high incidence of hyperglycemia with glucose loading and a reduced capacity to dispose of glucose (57). The vulnerability of preterm infants to hyperglycemia and the need to monitor glucose closely in the early neonatal period was established.

Infantile hypoglycemia has been studied on CRCs. Pagliara and colleagues (159) reported the hypoalaninemia was a consistent correlate of ketotic hypoglycemia. This observation has been interpreted to indicate a limitation of available substrate for glucose production by the liver during fasting. An understanding of ketotic hypoglycemia, the most common of the noninsulininduced childhood hypoglycemias, has led to improved management.

CRCs research has characterized inborn defects of liver gluconeogenesis in infants with severe congenital hypoglycemia. Baker and Winegrad (12) and Pagliara and co-workers (160) reported two cases of severe acidosis and hypoglycemia due to a deficiency of hepatic fructose 1,6-diphosphatase, one of the rate limiting enzymes in liver gluconeogenesis.

The mechansim of the most frequent type of insulin-induced hypoglycemia has been characterized in several neonates. Hyperinsulinism has been documented and successful partial pancreatectomy has been performed. Yakovac and colleagues (239) reported that pathologic studies of the pancreas showed a congenital abnormality in the insulin producing beta-cells in nine of 12 of these infants and children. This was the first description of nesidioblastosis, characterized by an abnormal distribution of beta-cells outside their usual site in the islets of Langerhans in the pancreas. These cells secrete abnormal amounts of insulin, apparently uninfluenced by the normal control mechanisms, 
resulting in fasting hyperinsulinism and hypoglycemia. Although most of these patients require surgery, some of these patients respond to the drug diazoxide (11).

Tyrosinemia. Studies performed in a Pediatric CRC have elucidated the biochemical abnormalities in hereditary hepatorenal tyrosinemia, a disorder of amino acid metabolism with hepatic, renal, liver, and bone involvement (112). Because this disorder is also associated with an increased incidence of hepatoma, an understanding of its pathophysiology is of considerable significance (232).

Extensive metabolic and enzymatic studies performed in a patient with hereditary hepatorenal tyrosinemia demonstrated a deficiency of red cell and hepatic glutathione (221). In addition, other hepatic enzymes not directly involved in tyrosine metabolism were noted to be affected. Succinylacetone (4.6-dioxoheptanoic acid), an abnormal metabolic product secondary to a fumarylacetoacetate hydrolase deficiency, was demonstrated in serum and urine, and was shown to inhibit delta-aminolevulinic acid dehydratase activity in vitro. Assay of mixed function oxidase activity demonstrated low levels of arylhydrocarbon hydroxylase and 7-ethoxycoumarindeethylase. This oxidase deficiency may result in decreased detoxification by the liver and an increased malignant potential.

When a diet low in phenylalanine, tyrosine, and methionine was instituted, these abnormalities improved, including an increase in red cell glutathione levels. Glutathione participates in the conjugation of foreign toxins and endogenous byproducts. Accordingly, a clinical trial at a Pediatric CRC was designed to increase glutathione levels in the liver. $N$-acetylcysteine has been successfully used in acetominophen toxicity because it prevents covalent bonding of acetominophen byproducts to hepatic microsomes (177). $N$-acetylcysteine is better than glutathione because it penetrates liver cells. Such treatment may inhibit the hepatic degeneration and malignant complications of this disorder.

Serial hepatic ultrasonograms in one patient disclosed a hepatoma detected before the development of clinical findings. The patient then received a successful liver transplant. She is the only living patient with tyrosinemia with a viable liver transplant, cured of the hepatic enzyme deficiency, and has no evidence of metastases.

\section{ENDOCRINE DISORDERS}

Introduction. Clinical and laboratory studies conducted at Pediatric CRCs have greatly contributed to the understanding of the physiologic development of the adrenal gland, as well as to the pathogenesis and genetics of disorders of adrenal function $(102,161-166,174,175,192)$. The adrenal gland produces two essential life-supporting hormones (mineralocorticoids and glucocorticoids); thus, advances in the knowledge of the development of the adrenal gland during perinatal life and deficiencies of these hormones have made it possible to develop diagnostic tests for genetic disorders of the adrenal gland applicable in the fetus and newborn.

Congenital adrenal hyperplasia. $\mathrm{CAH}$ is a group of inherited disorders of adrenal steroidogenesis. Each disorder results from a deficiency of one or more enzymes necessary for normal steroid synthesis.

The most common form of adrenal hyperplasia is caused by a deficiency of 21-hydroxylase. In this disorder mineralocorticoid and glucocorticoid hormone synthesis are decreased, whereas male sex hormone synthesis is increased. In the salt-wasting form of 21-hydroxylase deficiency, both male and female newborns are subject to early life-threatening salt-wasting crises, due to a severe deficiency of aldosterone. Virilization of external genitalia in female newborns may lead to incorrect sex assignment.

This disorder is very common in the native Alaskan Eskimo, and is also relatively common in the general Caucasian population with an incidence of 1 in 5000-13,000 live births. There was a need for an accurate test for diagnosis in the fetus at risk for this disorder. Further, a diagnostic test for early detection of CAH could prevent life-threatening illness in affected newborns. Such laboratory tests were not available until 1975.

Prenatal diagnosis of $\mathrm{CAH}$. The Cornell CRC developed techniques to measure steroid hormones in amniotic fluid. Reference data for various fetal adrenal and gonadal steroid hormone levels in amniotic fluid, from midgestation to term, have been established $(162,174,175)$. Studies of fetuses at risk for $\mathrm{CAH}$ at midgestation and at term indicated that measurement of $17-\mathrm{OH}$ progesterone and androstenedione concentrations in the amniotic fluid at midgestation and at term can be used in the prenatal diagnosis of CAH $(162,174,175)$.

Newborn screening for $C A H$. The Cornell CRC has developed a simple, inexpensive, and reliable laboratory screening test for $\mathrm{CAH}$ applicable to newborns. The hormone, $17-\mathrm{OH}$ progesterone, is measured using a drop of capillary blood from heel puncture impregnated on filter paper $(161,165,166)$. This is similar to the procedure used in mandated newborn screening programs for phenylketonuria and congenital hypothyroidism. The Core Laboratory of the CRC established normative data of $17-\mathrm{OH}$ progesterone concentrations in 4560 control newborns and reference data of $17-\mathrm{OH}$ progesterone levels in affected newborns. This technique was used in a pilot newborn screening program for $\mathrm{CAH}$ for newborns in Alaska.

In collaboration with the Public Health Department of Alaska and the Cornell CRC, 19,000 consecutive Alaskan newborns in a 30-mo period were screened, resulting in the discovery of four affected newborns who would not have been diagnosed until lifethreatening adrenal crises occurred. Analysis of the frequency indicates that this disorder occurs in 1:282 live births in Yupik Eskimos in Alaska, which is even more common than had been previously reported by case survey (1:490 live births). Overall, the occurrence of this disorder in Alaska in 1:3800 live births $(165,166)$.

Therapeutic monitoring of $C A H$. Endocrine research conducted at CRCs has contributed to the understanding of the development and maturation of adrenal and gonadal sex steroids from newborn to adult life $(102,163,164,192)$. This includes the development of radioimmunoassays for various steroid hormones on small quantities of blood. Using these techniques, the mechanisms of disorders of adrenal and gonadal maturation have been studied $(102,163,164)$.

These studies helped to identify the hormones that can be used to monitor the treatment of children with $\mathrm{CAH}$. Both $17-\mathrm{OH}$ progesterone and androstenedione levels can be used for the diagnosis and therapeutic monitoring in all age groups of patients, regardless of sex. Serum testosterone measurements are useful in female patients only, and could not be used in male infants or in pubertal males, due to the contribution of gonadal testosterone $(102,163,164)$.

Metabolic studies of sodium balance and the renin-angiotensin-mineralocorticoid system in children with either the saltlosing or non-salt-losing type of $\mathrm{CAH}$ have indicated the need for mineralocorticoid hormone replacement in both types (192) to permit optimal growth

Linkage of $\mathrm{CAH}$ gene with the major histocompatibility locus. The commonest form of congenital adrenal hyperplasia, a deficiency of 21-hydroxylase activity, is transmitted by an autosomal recessive gene $(16,36)$. Many investigators have attempted to demonstrate that the obligate heterozygote parents for 21-hydroxylase deficiency have a mild enzymatic deficiency that can be uncovered by hormonal testing $(17,36,37,84,85,87,98$, $103,113,178,193)$.

In 1977 the first report of linkage between the major histocompatibility locus and 21-hydroxylase deficiency was reported (56). In this report, HLA genotyping of leukocytes of six families of patients with $\mathrm{CAH}$ demonstrated that the gene for $\mathrm{CAH}$ segregated with the HLA complex, but could be separated by genetic recombination from the locus for HLA-A and GLO. In a subsequent collaborative study in Zurich and New York, studies in 34 families confirmed the previous findings, and mapped the 
gene for $\mathrm{CAH}$ on chromosome 6, close to the HLA-B locus. Statistical analysis of the linkage between CAH and HLA-B gave a peak Lod score of 9.5 , indicating close genetic linkage (118, 240). As a result of this linkage, the CAH genotype of families of patients with $\mathrm{CAH}$ could be predicted by HLA genotvping. A family member sharing one HLA haplotype with the affected patient would be a heterozygote carrier for 21 -hydroxylase deficiency whereas a family member sharing no haplotype with the patient would be unaffected. Extensive family studies confirmed this prediction. The $17-\mathrm{OH}$ progesterone response to $\mathrm{ACTH}$ in family members predicted by HLA genotyping to be heterozygote carriers of the gene for 21-hydroxylase deficiency, was significantly higher than that of the general population or family members predicted by HLA genotyping to be unaffected. Heterozygote family members have a mild 21 -hydroxylase deficiency which can be unmasked by ACTH stimulation $(120,121)$.

Cryptic and late-onset 21-hydroxylase deficiency. In the course of these studies, a previously unrecognized form of 21-hydroxylase deficiency was discovered, cryptic 21-hydroxylase deficiency. Family members with this disorder have elevated baseline 17-OH progesterone concentrations, which rise with ACTH stimulation to levels significantly higher than those of the heterozygote family members. Similarly, serum $\Delta 4$-androstenedione is elevated in the baseline and the ACTH-stimulated state. Despite the deficiency of 21 -hydroxylase activity, these family members are asymptomatic; they are of normal stature, have undergone normal puberty, and have normal fertility. These family members appear to be genetic hybrids, having one gene for the severe deficiency, inherited also by the index case with $\mathrm{CAH}$, and one gene for the mild cryptic 21 -hydroxylase deficiency. Cryptic 21 hydroxylase deficiency has also been demonstrated to be HLAlinked $(116,117)$.

CRC studies of families of patients presenting with "late-onset" adrenal hyperplasia have demonstrated that this 21 -hydroxylase deficiency is also transmitted by an autosomal recessive gene linked to HLA. The hormonal abnormalities of late-onset adrenal hyperplasia are similar to those of cryptic 21-hydroxylase deficiency, suggesting a similar degree of enzymatic deficiency. Further, both cryptic and late-onset adrenal hyperplasia are in genetic disequilibrium with the haplotype segment $\mathrm{B} 14, \mathrm{C} 4 \mathrm{~A} 2$, C4B2, Bfs, C2C, DR1; however, patients with late-onset 21hydroxylase deficiency present with variable signs of androgen excess, including early development of pubic hair, hirsutism, acne, and menstrual irregularities. HLA studies indicate that patients with "late-onset" adrenal hyperplasia may, like patients with cryptic $2 \mathrm{I}$-hydroxylase deficiency, have both the severe deficiency gene and the mild deficiency gene $(99,173)$.

As a result of these studies, nomograms were developed relating baseline and ACTH stimulated serum hormone concentrations in several groups including I) patients with $\mathrm{CAH}$, cryptic, and late-onset adrenal hyperplasia; 2) family members predicted by HLA genotyping to be heterozygotes for these disorders; 3 ) members of the general population; and 4) family members predicted by HLA genotyping to be unaffected by the gene for 21 -hydroxylase deficiency. These nomograms provide a means to diagnose 21-hydroxylase deficiency in the general population as well as in families with an affected member (140-143).

These studies suggest that $\mathrm{CAH}$, cryptic, and late-onset adrenal hyperplasia are due to allelic variants at the locus for steroid 21 hydroxylase. Cryptic and late-onset adrenal hyperplasia are closely related and may be due to the same allelic variant at the steroid 21 -hydroxylase locus $(116,117,153)$.

\section{PERINATAL NEUROLOGY}

Introduction. Along with the decreased infant mortality rate that occurred in the last $20 \mathrm{yr}$ there was an associated decrease in central nervous system morbidity in surviving children. Hospital-based studies in the United States reported rates beween
$10-40 \%$, with most values falling at the low end of the range $(2$, $44,61,157,167,184,188,216)$. Clearly, this is less than the 50 $75 \%$ morbidity reported in the literature of the late 1950 s (52, 122, 123).

The only available population-based studies of the changing incidence of cerebral palsy are those from Sweden for the period 1954-1974 (74). This report shows a decrease not only in the incidence of perinatal and neonatal mortality, but also in the overall incidence of cerebral palsy. The reduction was principally due to a drop in the incidence of spastic diplegia, especially in low birth weight infants. There was no reduction in spastic quadriplegia, the type of cerebral palsy most prevalent in asphyxiated full-term infants. As noted, data from hospitals in the USA over the past $20 \mathrm{yr}$ reveal a reduced incidence of neurologic sequelae in infants $<2500 \mathrm{~g}$ birth weight, and based on the Swedish data, a probable similar reduction among full-term infants.

Retrolental fibroplasia. Oxygen has been recognized as the major factor causing retrolental fibroplasia in very LBW infants; however, other factors also contribute to or potentiate the vasoobliterative effect of oxygen on the immature retina. Shahinian and Malackowski (200) reported that retrolental fibroplasia increases with decreasing gestational age, but its severity is not related to birth weight or gestational age. A comparison of preterm infants with and without retrolental fibroplasia revealed that arterial blood gas values were similar in the first week of life for both groups; however, during subsequent weeks, infants who developed severe retrolental fibroplasia had significantly more time when their capillary oxygen tension was at undesirable values $\left(\mathrm{P}_{\mathrm{cap}} \mathrm{O}_{\mathrm{a}}>50 \mathrm{~mm} \mathrm{Hg}\right)$ than in the mild retrolental fibroplasia or control infants. They suggest that infants are at greatest risk from oxygen given late in the perinatal period. Current CRC studies suggest that vitamin E may prevent or decrease the severity of retrolental fibroplasia if given early in the course of oxygen administration (78).

Metabolic factors affecting brain homeostasis. Several metabolic and physiologic abnormalities can be associated with significant central nervous system dysfunction/damage. These include asphyxia with impaired regulation of cerebral blood flow and/or shock, intracranial hemorrhage, hyponatremia, hypoglycemia, hyperbilirubinemia and sodium, calcium and magnesium electrolyte imbalance.

Dweck et al. (57) studied the effect of previous glucose exposure on glucose tolerance tests in preterm infants. Glucose exposure before the glucose tolerance tests resulted in higher mean plasma glucose, more frequent preinfusion hyperglycemia (glucose $>125 \mathrm{mg} / \mathrm{dl}$ ), and a greater proportion of slow glucose disappearance rates when compared with the fasted infant. The data indicate a diminished tolerance to glucose in low birth weight infants, the vulnerability of preterm infants to hyperglycemia, and the need to carefully monitor glucose in the early neonatal period.

Perlstein $e t$ al. (171) studied the adaptation of 19 healthy fullterm infants to cold during the first $3 \mathrm{~d}$ of life. They demonstrated that newborns who were exposed to short periods of cold during the first $2 \mathrm{~d}$ of life have an enhanced ability to maintain their core body temperature when subsequently challenged by a heatlosing environment. Because thermal stability is one of the physiologic parameters associated with improved neurologic outcome, prevention of thermal stress is re-emphasized.

Neurologic development. Amiel-Tison (4) described the neurologic evaluation of th newborn infant based on an evaluation of passive and active tone, and primary reflexes. They showed how gestational age can be assessed at birth from the neurologic examination, thus distinguishing between preterm low birth weight infants and full-term infants of similar birth weight. With the development of this important evaluation tool, an increased interest in the neonatal neurologic examination was stimulated.

The follow-up evaluation of patients surviving specialized 
perinatal care give some measure of the success of changes in care over the past $20 \mathrm{yr}$. Johnson et al. (92) describe the followup of 66 surviving infants from a total of 196 ventilated infants born between 1962 and 1969. Of the 55 long-term survivors, $80 \%$ had normal intelligence with either minimal or no neurologic abnormalities.

The neurologic abnormalities in surviving children usually consist of spasticity, hearing loss, vision loss, and seizure disorder. Mental retardation also occurred with and without motor deficits. Four children were handicapped but had normal IQs. Eighteen of the study group with IQ $<85$ had some form of learning or behavior disorder. Several other studies from the 1960 s confirm these findings.

Driscoll et al. (53) reported on the outcome of 54 infants born in 1977 and 1978 with birth weights of $1000 \mathrm{~g}$ or less. The incidence of neurologic deficits was $17 \%$ and the incidence of intellectual deficits was $13 \%$. The major perinatal factor leading to neonatal mortality and subsequent morbidity was birth asphyxia. Twenty-six percent of the surviving infants had retrolental fibroplasia, but it usually was not severe. Sepsis was a significant factor in neonatal mortality in 10 of 28 infants. The authors comment that "although our incidence of disabling neurologic disorders is lower than in earlier reports for this weight group, the total longitudinal complication rate including intellectual impairment is still 30\%." These authors believe that further improvement in intellectual outcome awaits prevention of perinatal asphyxia.

Zarin-Ackerman et al. (243) studied language development in two groups of 2-yr-old infants matched for social class but differing in birth conditions. One high risk group consisted of infants who suffered from birth asphyxia, hypercalcemia, and hyperglycemia whereas the other group contained normal infants. The high risk group had poorer language performance but little difference in perceptual cognitive development. These children will be followed for evaluation of abstract reasoning, memory and language.

Neuropathology. Brand et al. (21) in 1972, described the neuropathologic lesions of infants wiht RDS who survived from 12 $\mathrm{h}$ to $10 \mathrm{mo}$. The principal lesions in the central nervous system were fibrillary gliosis and increased vascularization, largely of the white matter. More severe lesions were present in the older patients. Lesions in gray matter were less significant. They included severe neuronal damage of the dorsal motor vagal nuclei, cerebellar Purkinje cell layer, or various auditory-cochlear nuclei. There was a $46 \%$ incidence of subependymal germinal matrix hemorrhage/intraventricular hemorrhage. Those with intracranial bleeding either died in the perinatal period or lived without any evidence of significant residual histologic effects. This paper is particularly important because it showed that lesions of preterm babies were primarily in the central portion of the brain rather than the cortical mantles.

Neurophysiological studies. Several studies of the fetal EEG suggest that it can be recorded successfully in utero and does not change abruptly at birth $(30,33-35)$. A computer program is useful for fetal EEG analysis, avoiding problems of visual interpretation. Mixed activity is dominant in the fetal EEGs of normal infants. Low voltage irregular activity occurs significantly more frequently in fetal EEGs of infants later found to be neurologically abnormal at $1 \mathrm{yr}$. Increased low voltage irregular activity in the fetal EEG appears to be associated with lower Apgar scores. Fetal EEG patterns, through discriminant function analysis, may be useful in predicting neurologic outcome at $1 \mathrm{yr}$ of age.

These data provide some ability to identify the infant, at the earliest possible time after birth, whose central nervous system is altered sufficiently to cause permanent damage. One major difficulty is the inability to determine the length, severity, and acuteness of onset of an episode of intrauterine asphyxia. If the fetal EEG (because it does not change abruptly at birth) can be used immediately after birth, a neurologically injured infant may be identified early and immediate therapy instituted in an attempt to reduce permanent damage.

\section{PERINATAL IMMUNOLOGY}

Treatment of immunodeficiency. Infants with severe defects of the immune system, particularly the $T$ lymphocyte system, usually become ill in the first months of life and often are referred to medical centers with CRCs who have specialized staff and facilities to diagnose and care for such infants. One such child, David, a child with severe combined immunodeficiency, has been kept in a germ-free environment ("bubble") to prevent infection. Physicians at the CRC at Houston have devised a portable chamber so that he can go home inside his germ-free environment (236). Although considerable insight into the disease and toward maintaining a germ-free environment was gleaned from this experience, this is not a practical means of caring for such infants.

At other centers the emphasis has been on restoration of immunity by transplantation of immunologically active tissue. This is a highly successful procedure when a histocompatible sibling is available as a donor; indeed, bone marrow transplantation, here and abroad, have successfully reconstituted 100 or more of such infants, allowing them to live a near normal life free of infection (115). Most infants in the USA have been cared for in CRCs.

When such a donor is unavailable, alternative strategies have been employed. Cooper et al. (39) suggested that defects in stem cells were responsible for severe combined immunodeficiency in some instances, and demonstrated that fetal liver, the earliest lymphoid organ, could be used to provide stem cells devoid of graft-versus-host reactivity. Buckley and associates (25) at the Duke CRC performed a fetal liver transplant in a girl with severe combined immunodeficiency that has survived $6 \mathrm{yr}$. Although graft rejection is not a problem, graft-versus-host disease can be formidable, necessitating fetal liver from a donor less than $12 \mathrm{wk}$ of gestation. Perhaps $10-15 \%$ of severe combined immunodeficiency patients transplanted with fetal livers are long-term survivors.

Fetal thymus transplants have been used successfully in children with pure $\mathrm{T}$ cell deficiency, especially in patients with thymic aplasia (DiGeorge syndrome) (8). Thymic hormone therapy has also been utilized with some success (231).

Bone marrow transplantation in children with other immunodeficiencies have been accomplished. Parkman et al. (168) at the CRC at Boston Children's Hospital have reported the correction of the hematologic and immunologic defects of the WiskottAldrich syndrome utilizing irradiation for marrow engraftment. Most recently, bone marrow transplantation of combined immunodeficiency has been achieved utilizing marrow from a parent who was mismatched at one-half of the HLA loci. The parental marrow was treated with a monoclonal antibody to remove those $T$ cells which cause graft-versus-host disease (185). Alternatively, Kapoor et al. (93) have used soybean agglutinin and $E$ rosetting techniques to remove mature $T$ cells that cause GVH reactions. These therapies may permit widespread transplantation because a sibling donor is not necessary.

Adenosine deaminase deficiency and immunodeficiency. A significant advance in the understanding of severe combined immunodeficiency was the discovery that one form of the disease, comprising about $10 \%$ of the total of patients with severe combined immunodeficiency, is associated with a deficiency of the enzyme ADA (132). ADA is an enzyme which deaminates adenosine to inosine in the purine salvage pathway, and its deficiency was the first described biochemical defect resulting in immunodeficiency. Two other enzyme deficiencies have subsequently been associated with immunodeficiency: NP, an enzyme which converts inosine to hypoxanthine in the purine salvage pathway, and 5'-nucleotidase, an enzyme which converts mon- 
ophosphorylated nucleosides to nucleosides and phosphate. NP deficiency has been associated with severe $T$ lymphocyte deficiency (198) whereas nucleotidase deficiency has been associated with several B lymphocyte antibody deficiencies (59).

Meuwissen and associates (132), at the Albany, NY CRC summarized their findings in 13 patients with SCID and ADA deficiency. The defect, transmitted as an autosomal recessive trait, is often associated with radiographic abnormalities of the skeleton, and leads to thymic involution after birth. Erythrocytes are a convenient tissue for assay of ADA activity. In fact, a few drops of blood collected on filter paper were sufficient for screening newborns suspected of the disease.

One possible mechanism of action of ADA deficiency is the metabolic build up of deoxyadenosine. Mitchell and associates (133) showed that this metabolite is greatly elevated in the triphosphorylated form in ADA deficiency and is extremely toxic to $T$ lymphoblastoid cell lines, but not to $B$ cell lines. Deoxyguanosine also displayed this selective toxic effect. It is known that deoxyadenosine triphosphate is a potent inhibitor of ribonucleotide reductase, an enzyme that converts cytidine diphosphate to the deoxy form which is phosphorylated and, ultimately, incorporated into DNA. Although the profound T cell inhibition may be explained by this theory the B cell dysfunction in ADA deficiency cannot be explained. It is possible that loss of helper $T$ cells, which cooperate with $\mathrm{B}$ cells for antibody production, is defective. An alternate explanation is that deoxyadenosine inhibits S-adenosylhomocysteine hydrolase and allows the buildup of S-adenosylhomocysteine, which in turn inhibits important methylation pathways.

In addition to the complete absence of key enzymes producing a state of immunodeficiency, Fox et al. (62) at the Michigan CRC discovered a partial NP deficiency with immunodeficiency, involving a mutant NP enzyme. The mutant enzyme differed from the normal NP enzyme by a 10 -fold greater binding constant for substrate, by being more susceptible to thermal inactivation, and by bearing more cationic groups. It is likely that the altered properties of the mutant enzyme account for the mild immunodeficiency.

Enzyme replacement therapy in SCID-ADA deficient patients has been attempted utilizing normal erythrocytes, rich in ADA. Polmar and associates (176) at the Case Western Reserve CRC reversed the lymphocyte defects in a patient with ADA deficiency by giving repeated red cell transfusions. Initial enthusiasm for this mode of therapy was tempered by the report of Schmalstieg et al. (199) at the University of Texas, Galveston CRC who noted only a partial response to red cell and plasma transfusions. This therapy does not permanently correct the enzyme deficiency, and biochemical and immunologic relapse occurs when the erythrocyte transfusions are stopped. Nevertheless, these studies suggest the possibility of immunoreconstitution when more suitable forms of enzyme replacement become available.

Another association of enzyme deficiency with immunodeficiency was reported by Cowan et al. (40) at the University of California, San Francisco CRC who reported three siblings with impaired $T$ and $B$ cell responses in biotin-dependent carboxylase deficiency. These children presented with neurologic abnormalities, intermittent lactic acidosis, and raised urinary levels of $\beta$ hydroxypropionate, methylcitrate, $\beta$-methylcrotonylglycine, and $\beta$-hydroxyisovaleric acid which were responsive to biotin therapy.

Intravenous immunoglobulin replacement therapy. In antibody deficiency disorders it is desirable to maintain IgG levels as close as possible to the normal level. Such therapy minimizes infectious complications and improves the likelihood of prolonged symptom-free survival. Beginning in the 1950 s the gammaglobulin (Cohn II) fraction of serum, obtained by alcohol and low temperature fractionation, was used to treat hypogammaglobulinemic individuals. This gammaglobulin preparation forms aggregates which, if given intravenously, activates the complement and kinin systems and produces severe anaphylactic reactions (and death in a few instances). Generally, gammaglobulin $(0.7$ $\mathrm{ml} / \mathrm{kg}$ of body weight) is given by intramuscular injection once per month (i.e., $50 \mathrm{ml}$ in a $70 \mathrm{~kg}$ subject). This dose raises the serum concentration by $100-200 \mathrm{mg} / \mathrm{dl}$ and greatly reduces the morbidity of infections. Local complications of intramuscular gammaglobulin include sterile abscesses, tenderness, fibrosis, and sciatic nerve injury. Intramuscular injections are particularly difficult to administer to malnourished infants with immunodeficiency because of poor muscle mass.

It was thus desirable to develop a safe and effective immunoglobulin for intravenous use. Nolte et al. (144) at the Oregon CRC administered intravenously a modified IgG that was reduced and alkylated to 20 hypogammaglobulinemic patients. The mean immediate serum concentration rise was $248 \mathrm{mg} / \mathrm{dl}$ compared to a mean $90 \mathrm{mg} / \mathrm{dl}$ rise after intramuscular injections. More importantly, the acute infection rate in the intravenous group was $30 \%$ of that in the intramuscular group $(P<0.05)$. Mild but bothersome side effects of the intravenous IgG occurred in $50 \%$ of patients and included nausea, flushing, fever, muscle cramps, and headache.

A 1980 follow-up study from the Oregon, Duke, and the University of Washington CRCs compared the intravenous use of reduced and alkylated IgG alone or in the presence of a 10 $\mathrm{mg} / \mathrm{dl}$ solution of maltose stabilizer (148). They noted a remarkable reduction in side effects with the IgG-maltose infusion ( 3 of 29 patients versus 22 of $29, P<0.001$ ). They concluded that the IgG-maltose preparation was a safe and efficient agent for use in IgG immunodeficiency diseases.

Ammann and associates (5) in a large CRC multicenter (University of California, San Francisco, UCLA, Duke, University of Washington) trial compared this modified IgG (intravenous) with standard intramuscular IgG and demonstrated that the intravenous preparation was as effective in preventing major infections. It is particularly valuable for patients requiring large volumes of IgG or who do not tolerate large intramuscular injections. Mease et al. (130) at the University of Washington CRC demonstrated the therapeutic efficacy of this intravenous $\mathrm{IgG}$ in reversing the encephalom yelitis and dematomyositis-like complications occurring in X-linked agammaglobulinemia refractory to intramuscular IgG. Indeed, this IV preparation has now been released for routine use and is finding widespread clinical applicability.

Viral infections of the newborn. It is estimated that 6-8\% of all live births are complicated by viral infections as contrasted to $1-2 \%$ by bacterial infections (Table 1) (158). Viral infections of the newborn can be acquired before, at, or immediately after birth. Major sequelae of these infections include abortion, stillbirth, congenital malformation, prematurity, intrauterine growth retardation, spastic movement disorders, acute disease at birth, persistent postnatal infections, mental retardation and attention deficit disorders. Systemic viral illness in the mother can reach the fetus by replication through the placenta, or by transplacental passage of infected maternal lymphocytes. Postnatally, passage of the newborn through an infected birth canal and ingestion of

Table 1. Approximate frequency of infections in the mother during pregnancy and in the newborn infant*

\begin{tabular}{lcc}
\hline \multicolumn{1}{c}{ Virus } & Mother & Neonate \\
\cline { 2 - 3 } & $\begin{array}{c}\text { No./1000 } \\
\text { pregnancies }\end{array}$ & $\begin{array}{c}\text { No./1000 } \\
\text { live births }\end{array}$ \\
\hline $\begin{array}{l}\text { Cytomegalovirus } \\
\text { During pregnancy, congenital }\end{array}$ & $10-70$ & $6-34$ \\
$\quad$ At delivery, natal & $30-130$ & $20-70$ \\
Rubella & & \\
$\quad$ I964 epidemic & $20-40$ & $3-7$ \\
Interepidemic prevaccine & $0.1-2.0$ & $0.1-0.7$ \\
$\quad$ Postvaccine & $0.03-0.7$ & $0.03-0.2$ \\
Hepatitis B & $1-160$ & $0-61$ \\
Herpes simplex & $1-10$ & $0.03-0.3$ \\
\hline
\end{tabular}

* Overall, J. C., Jr. (158): Viral infections of the fetus and neonate. In: Feigin, R. D., and Cherry, J. D.: Textbook of Pediatric Infectious Diseases. p. 688 (W. B. Saunders Co., Philadelphia, 1981). 
maternal secretions including breast milk are also important routes of acquisition of viral infections.

The frequency of viral infections in mothers and infants has been obtained in large part from the work of Overall (158) at the University of Utah and Stagno et al. (215) at the Alabama CRC. The immunity of the mother to CMV was thought to protect their infants from congenital CMV infections; however, Stagno et al. (213) made the unanticipated discovery that congenital $\mathrm{CMV}$ infections occurred as frequently in infants of immune mothers $(3.4 \%)$ as in the general population $(2.4 \%)$, leading to the conclusion that maternal antibodies do not completely protect the fetus from CMV infection and suggesting that future CMV vaccines may not be effective $(213,215)$. The situation with CMV contrasts with that of congenital rubella in which immune mothers rarely produce affected infants and rubella vaccine has proven highly efficacious.

Perinatal CMV infection. CMV is an ubiquitous virus infecting individuals whose immune systems are suppressed or altered. Although it is possible for an infant to acquire nosocomial CMV infections such as that from a blood transfusion [as noted by Yeager et al. (241) at the Stanford CRC], the major source of the virus is the mother. Investigators at the Alabama CRC estimate that $60-90 \%$ of women in child-bearing years have CMV antibody and 3-18\% secrete the virus from the cervix and $3-9 \%$ excrete the virus in the urine (215). CMV virus infection is associated with decreased cellular immunity, including decreased lymphocyte blastogenesis, decreased immune interferon production, and decreased numbers of $T$ lymphocytes; thus, CMV infection may induce a secondary immunodeficiency rendering the infant susceptible to additional infections for a prolonged period of time. Reynolds et al. (186) showed that the humoral antibody response to measles-mumps-rubella immunization in CMV-infected infants was no different than in control infants. The CMV-infected infant has some immunologic responses unlike the rubella-infected infant who suffers profound suppression of both cellular and humoral immunity.

The tests used to diagnose perinatal infection include microscopic examination for viral inclusions, culture of the virus, detection of viral antigens in cells by immunologic methods, and determination of specific serum antibodies. A comparative study of these diagnostic procedures was made by Stagno et al. (214) at the Alabama CRC and Emory. Total serum IgM concentration $>20 \mathrm{mg} / \mathrm{dl}$ identified only $33 \%$ of the CMV-infected infants and there was a $3.1 \%$ false-positive rate. The indirect immunofluorescent $\operatorname{IgM}$ antibody test identified $76 \%$ of infected neonates but there was a $21 \%$ false-positive rate. A rheumatoid factor test, although non-specific for CMV, correctly identified $35 \%$ of the infected infants with no false-positive tests. A rapid diagnosis (24 h) was made in $91 \%$ of culture proven cases by culturing the urine on cell lines and examining the cell nuclei for CMV antigens by immunofluorescence. Similarly, $92 \%$ of cases could be identified by electron microscopy; thus, a simple and rapid assessment of potentially CMV-infected neonates is available in most instances.

Clinical trials of the antiviral agents iododesdoxuridine, 5fluorodeoxyuridine, cytosine arabinoside, adenine arabinoside, interferon inducers, and human interferon have not altered the course of CMV disease. For example, Arvin et al. (7) at the Stanford CRC gave human interferon to five infants with symptomatic CMV infections. Transient suppression of viruria was noted only with a large interferon dose $\left(3.5 \times 10^{5}\right.$ reference unit . $\mathrm{kg}^{-1} \cdot \mathrm{d}^{-1}$ ) but no clinical efficacy could be demonstrated.

The long range importance of these studies on the diagnosis and attempted treatment of CMV infections is emphasized by Reynolds et al. (187) who showed that even asymptomatic CMV infected infants can later suffer progressive hearing impairment, mental deficiency, and school failure. The longitudinal studies were only possible because of the unique design of the Alabama CRC which permits continuing outpatient assessment and study.

Perinatal herpes simplex infection. Type $2 \mathrm{HSV}$ infection is responsible for $70 \%$ of newborn HSV infections whereas Type 1
HSV is responsible for $30 \%$. The mother is the usual source of $\mathrm{HSV}$ and her genital tract is the site of infection in $75 \%$ of cases. Only about one-third of pregnant women with documented Type 2 HSV actually have genital lesions, however. Congenital HSV infection occurring by transplacental passage of virus is usually associated with severe central nervous system damage (destruction of brain tissue, microcephaly, intracranial calcifications, chorioretinitis) in a high proportion of cases. Perinatal or postnatal HSV infections resemble infections with bacterial agents: fever, lethargy, vomiting, respiratory distress, and cyanosis are common. Among infants with disseminated HSV infections $90 \%$ either die or are left with major neurologic disorders. Including infants with localized HSV infection, the overall prognosis is poor, with a $61 \%$ mortality and a $19 \%$ incidence of significant central nervous system problems.

Treatment of neonatal HSV infections is unsatisfactory. The natural history of the disease is incompletely understood. Local herpetic lesions may progress to systemic disease with central nervous system involvement, but others remain localized. Because systemic disease has a higher morbidity and mortality rate than does localized disease, evaluation of treatment is difficult. Antiviral agents work better when they are started early in the illness, yet up to $33 \%$ of neonates may not display evidence of HSV infection. Antiviral drugs have more severe side effects in neonates than in older children. Other important variables include the effects of maternal antibody, primary versus recurrent maternal HSV infection and Type 1 versus Type 2 HSV infection. Accordingly, multi-institutional collaborative studies have been initiated utilizing CRCs in various locations. The first such study demonstrated that iododeoxyuridine and cytosine arabinoside did not alter the outcome of congenital HSV infection; in addition, severe toxicity precluded their continued use in these infants (18). Adenine arabinoside, however, has been shown to be an effective antiviral agent for HSV encephalitis in neonates as well as adults, reducing the death or sequelae fram $67-85$ to $28-36 \%$. Whitley et al. (234) and the National Institutes of Allergy and Infectious Diseases Collaborative Antiviral Study Group documented the effectiveness of adenine arabinoisde (versus placebo) in biopsy-proven HSV (Type 1) encephalitis in adults. Treatment was without serious side effects and reduced the mortality from 70 to $28 \%$ in 18 drug-treated patients; $50 \%$ of survivors had moderate to absent debilitating neurologic sequelae. Another collaborative study evaluated adenosine arabinoside in neonates in a randomized, double-blind, and placebocontrolled study involving $56 \mathrm{HSV}$-infected infants. The mortality in babies with central nervous system and disseminated disease was reduced from $74 \%$ to $38 \%(P=0.014)$. Overall, neurologic sequelae occurred in $50 \%$ of the surviving treated group but $87 \%$ of the surviving placebo control. No acute toxicity was identified and there was no adverse central nervous sytem effects.

The newest antiviral agent is acycloguanosine (Acyclovir), an acyclic nucleoside, that is converted to an active form only by a herpes virus-specific thymidine kinase. The drug blocks DNA synthesis in virus-infected cells leaving uninfected cells unaffected. At present Acyclovir is being used in a NIH-sponsored collaborative study of neonatal HSV infection utilizing CRCs throughout the country.

\section{REFERENCES AND NOTES}

1. Abitbol, C. L.. Feldeman. D. B., Ahmann. P., and Rudman, D.: Plasma amino acid patterns during supplemental intravenous nutrition of lowbirth weight infants. J. Pediatr.. 86: 766 (1975)

2. Alden, E. R., Mandelkorn, T., Woodrum, D. E., Wennberg, R. P., Parks, C R., and Hodson, W. A.: Morbidity and mortality of infants weighing less than 1.000 grams in an intensive care nursery. Peditrics, 50:40 (1972).

3. Allan, J. D., Cusworth, D. C., Dent, C. E., and Wilson, V. K.: A disease, probably hereditary, characterized by severe mental deficiency and a constant gross abnormality of amino acid metabolism. Lancet, 1: 182 (1958).

4. Amiel-Tison, C.: Neurological evaluation of the maturity of newborn infants. Arch. Dis. Child., 43: 89 (1968)

5. Ammann. A. J., Ashman, R. F., Buckley, R. H., Hardie, W. R., Krantmann, H. J.. Nelson, J., Ochs, H., Stiehm, E. R., Tiller, T., Wara, D. W., and 
Wedgwood, R.: Use of intravenous $\gamma$-globulin in antibody immunodeficiency: results of a multicenter controlled trial. Clin. Immunol. Immunopath., 22: 60 (1982).

6. Anderson T. L.. Muttart, C. R., Bieber, M. A., Nicholson, J. F., and Heird, W. C.: A controlled trial of glucose versus glucose and amino acids in premature infants. J. Pediatr., 94: 947 (1979).

7. Arvin, A. M., Yeager, A. S., and Merigan, T. C.: Effect of leukocyte interferon on urinary excretion of cytomegalovirus by infants. J. Infect. Dis., 133 Suppl: A205 (1976).

8. August, C. S., Rosen, F. S., Filler, R. M., Janeway, C. A., Markowski, B., and Kay, H. E. M.: Implantation of a foetal thymus, restoring immunological competence in a patient with thymic aplasia (DiGeorge's syndrome). Lancet, 2: 1210 (1968).

9. Avery, M. E., and Mead, J.: Surface properties in relation to atelectasis and hyaline membrane discase. Am. J. Dis. Child., 97: 517 (1959).

10. Bakay, B., Nissensen. E. Sweetman, L., Francke, U., and Nyhan, W. L.: Utilization of purines by an HPRT variant in an intelligent, nonmutilative patient with features of the Lesch-Nyhan syndrome. Pediatr. Res., 13: 1365 (1979).

11. Baker, L., Kaye, R., Root, A. W., and Prasad, A. L. N.: Diazoxide treatment of idiopathic hypoglycemia of infancy. J. Pediatr., 71: 494 (1967).

12. Baker, L., and Winegrad, A. I.: Fasting hypoglycemia and metabolic acidosis associated with a deficiency of hepatic fructose-1,6-diphosphatase activity. Lancet. 2: $13(1970)$.

13. Barness, L. A., and Morrow, G. III: Methylmalonic aciduria: a newly discovered inborn error (Editorial Notes). Ann. Intern. Med., 69: 633 (1968).

14. Barr, P. A., Bailey, P. E., Sumners, J., and Cassady, G.: Relation between arterial blood pressure and blood volume and effect of infused albumin in sick preterm infants. Pediatrics, 60: 282 (1977).

15. Batshaw, M., Brusilow, S., and Walser, M.: Treatment of carbamyl phosphate synthetase deficiency with keto analogues of essential amino acids. N. Engl. J. Med., 292: 1085 (1975).

16. Fentinck, R. C., Hinman, F., Sr., Lisser, H., and Traut, H. F.: The familial congenital adrenal syndrome: Report of two cases and review of the literature. Postgrad. Med., 11: 301 (1952).

17. Bergada. C., Rivarola, M. A., and Cullen. M.: Response to metopiron in parents of patients with congenital adrenal hyperplasia. Abstract. Seventh Pan American Congress of Endocrinology. Excerpta Medica International Congress Series., No. 99: 130/287 (1965).

18. Boston Interhospital Virus Study Group and the NIAID sponsored cooperative antiviral clinical study. Failure of high dose 5-iodo- $2^{\prime}$-deoxyuridine for herpes simplex encephalitis. Evidence of unacceptable toxicity. N. Engl. J. Med., 292: 599 (1975).

19. Bottoms, S. F., Rosen, M. G., and Sokol, R. J.: The increase in the cesarean birth rate. N. Engl. J. Med., 302: 559 (1980).

20. Bottoms, S. F., Sokol, R. J., and Rosen, M. G.: Short arrest of cervical dilation: a risk for maternal/fetal/infant morbidity. Am. J. Obstet. Gynecol., /40: 108 (1981)

21. Brand, M. M., Durbridge, T. C., Rosan, R. C., and Northway, W. H., Jr.: Neuropathological lesions in respiratory distress syndrome: acute and chronic changes during hypoxia and oxygen therapy. J. Reprod. Med., 8 267 (1972).

22. Bray, P. F., Herbst, J. J., Johnson, D. G., Book, L. S., Ziter, F. A., and Condon, V. R.: Childhood gastroesophageal reflux. Neurologic and psychiatric syndromes mimicked. JAMA., 237: 1342 (1977).

23. Broviac. J. W., Cole, J. J., and Scribner, B. H.: A silicone rubber atrial catheter for prolonged parenteral alimentation. Surg. Gynecol. Obstet., 136: 602 (1973).

24. Brusilow, S. W., Valle. D. L., and Batshaw. M.: New pathways of nitrogen excretion in inborn errors of urea synthesis. Lancet, 2: 452 (1979).

25. Buckley, R. H., Whisnant, J. K.. Schiff, R. I., Gilbertsen, R. B., Huang, A. T., and Platt, M. S.: Correction of severe combined immunodeficiency by fetal liver cells. N. Engl. J. Med., 294: 1076 (1976).

26. Campbell, A. G. M., Rosenberg, L. E., Snodgrass, P. J., and Nuzum, C. T. Ornithine transcarbamylase deficiency: a cause of lethal neonatal hyperammonemia in males. N. Engl. J. Med., 288: 1 (1973).

27. Chik, L., Hirsch, V. J., Sokol, R. J., and Rosen, M. G.: Temporal characterization of intrauterine pressure data. Am. J. Obstet. Gynecol., 120: 496 (1974).

28. Chik, L., Hirsch, V. J., Sokol, R. J., and Rosen, M. G.: An optimized algorithm for the detection of uterine contractions in intrauterine pressure recordings. Comput. Biomed. Res., 8: 294 (1975).

29. Chik, L., Rosen, M. G., Hirsch, V. J., and Sokol, R. J.: Programmed identification of fetal heart rate deceleration patterns. Am. J. Obstet. Gynecol., 119:816 (1974).

30. Chik, L., Rosen. M. G., and Sokol, R. J.: An interactive computer program for studying fetal electroencephalograms. J. Reprod. Med. 14.154 (1975).

31. Chik. L., Sokol, R. J., Kooi, R., Pillay, S., Hirsch, J., and Zador, I.: A perinatal database management system. Methods Int. Med., 20:133 (1981).

32. Chik, L.. Sokol, R. J., and Rosen, M. G.: "Prediction" of the one-minute Apgar score from fetal heart rate data. Obstet. Gynecol, 48: 452 (1976).

33. Chik, L., Sokol, R. J., Rosen, M. G., and Borgstedt, A. D.: Computer interpreted fetal electroencephalogram. I. Relative frequency of patterns. Am. J. Obstet. Gynecol., 125: 537 (1976).

34. Chik, L., Sokol, R. J., Rosen, M. G., and Borgstedt, A. D.: Computer interpreted fetal electroencephalogram. II. Patterns in infants who were neurologically abnormal at 1 year of age. Am. J. Obstet. Gynecol., 125: $541(1976)$.
35. Chik, L.. Sokol. R. J., Rosen, M. G.. Regula, G. A., and Borgstedt. A. D.: Computer interpreted fetal monitoring data. J. Pediatr.. 90: 985 (1977).

36. Childs. B.. Grumbach, M. M., and Van Wyk. J. J.: Virilizing adrenal hyperplasia: a genetic and hormonal study. J. Clin. Invest. 35: 213 (1956).

37. Cleveland, W. W.. Nikezic, M., and Migeon, C. J.: Response to an $11-\beta$ hydroxylase inhibitor (SU-4885) in males with adrenal hyperplasia and in their parents. J. Clin. Endocrinol. Metab., 22: 281 (1962).

38. Cohen, R. S., Stevenson, D. K. Malachowski, N., Ariagno, R. L., Johnson, J. D., and Sunshine, P.: Late morbidity among survivors of respiratory failure treated with tolazinine. J. Pediatr., 97:644 (1980).

39. Cooper. M. D., Keightley, R. G., Wu, L. Y. F., and Lawton, A. R., III: Developmental defects of $\mathrm{T}$ and $\mathrm{B}$ cell lines in humans. Transplant. Rev. 16: 51 (1973).

40. Cowan, M. J., Wara, D., Packman, S., Ammann, A. J., Yoshino. M. Sweetman. L., and Nyhan, W.: Multiple biotin-dependent carboxylase deficiencies associated with defects in T-cell and B-cell immunity. Lancet, 2: $115(1979)$

41. Culpepper, W., Kolff, J., Lin, C-Y., Vitullo, D., Lamberti, J., Arcilla, R. A., and Replogle. R. L.: Complete common atrioventricular canal in infancy-surgical repair and postoperative hemodynamics. Circulation, 58: 550 (1978).

42. Daily. W. J. R., Klaus, M., and Meyer, H. B. P.: Apnea in premature infants: monitoring, incidence, heart rate changes, and an effect of environmental temperature. Pediatrics, 43: 510 (1969).

43. Daily, W. J. R., Meyer, H. B. P.. Sunshine, P., and Smith, P. C.: Mechanical ventilation of newborn infants. IlI. Historical comments and development of a scoring system for selection of infants. Anesthesiology, 34:119 (1971).

44. Daily, W. J. R., Sunshine, P., and Smith, P. C.: Mechanical ventilation of newborn infants. V. Five years experience. Anesthesiology, 34:132 (1971).

45. Darnall, R. A., Jr. and Ariagno, R. L.: Minimal oxygen consumption in infants cared for under overhead radiant warmers compared with conventional incubators. J. Pediatr., 93: 283 (1978).

46. Darnall, R. A., Jr. and Ariagno, R. L.: Resting oxygen consumption of premature infants covered with a plastic thermal blanket. Pediatrics, 63: 547 (1979).

47. DeMcester, T. R., Wang, C-I., Wernly, J. A., Pellegrini, C. A.. Little, A. G., Klementschitsch, P.. Bermudez, G., Johnson, L. F., and Skinner, D. B.: Technique, indications and clinical use of 24 hour esophageal $\mathrm{pH}$ monitoring. J. Thorac. Cardiovasc. Surg., 79: 656 (1980).

48. DeVore. G. R., Mahoney, M. J., and Hobbins, J. C.: Antenatal diagnosis of haemoglobinopathies, haemophilia, Von Willebrand's disease, Duchenne's muscular dystrophy, and chronic granulomatous disease by fetal blood analysis. Clin. Obstet. Gynaecol., 7: 41 (1980)

49. Donovan, E. F., Tsang, R. C.. Steichen, J. J., Strub, R. J., Chen, I-W., and Chen, M.: Neonatal hypermagnesemia: Effect on parathyroid hormone and calcium homeostasis. J. Pediatr., 96: 305 (1980).

50. Dozy, A. M., Forman, E. N., Abuelo, D. N., Barsel-Bowers, G.. Mahoney, M. J., Forget, B. G.. and Kan, Y. W.: Prenatal diagnosis of homozygous $\alpha$-Thalassemia. J. Am. Med. Assoc., 241: 1610 (1979).

51. Drillien. C. M.: The Growth and Development of the Prematurely Born Infant. (Livingston, Edinburgh, 1964).

52. Drillien, C. M.: The long-term prospects for babies of low birth weight. Hosp. Med. (London), I: 937 (1967).

53. Driscoll, J. M., Driscoll, Y. T., Steir, M. E., Stark, R. I., Dangman, B. C., Perez, A., Wung, J-T., and Kritz, P.: Mortality and morbidity in infants less than 1.001 grams birth weight. Pediatrics, 69: 21 (1982).

54. Driscoll, J. M., Heird, W. C., Schullinger, J. N., Gongaware, R. D., and Winters, R. W.: Total intravenous alimentation in low-birth weight infants: a preliminary report. J. Pediatr., 81: 145 (1972).

55. Dudrick, S. J., Wilmore, D. W., Vars, H. M., and Rhoads, J. E.: Long-term total parenteral nutrition with growth development and positive nitrogen balance. Surgery, 64: 134 (1968).

56. Dupont, B., Oberfield, S. E., Smithwick, E. M., Lee, T. D., and Levine, L. S.: Close genetic linkage between HLA and congenital adrenal hyperplasia (21-hydroxylase deficiency). Lancet 2: 1309 (1977).

57. Dweck, H. S Brans, Y. W. Sumners, J. E. and Cassady, G.: Glucose intolerance in infants of very low birth weight. II. Intravenous glucose tolerance tests in infants of birth weights $500-1,380$ grams. Biol. Neonate., 30: 261 (1976).

58. Edwards, D. K.. Dyer, W. M., and Northway, W. H., Ir.: Twelve years experience with bronchopulmonary dysplasia. Pediatrics, 59:839 (1977).

59. Edwards, N. L., Magilavy, D. B., Cassidy, J. T., and Fox, I. H.: Lymphocyte ecto-5' -nucleotidase deficiency in agammaglobulinemia. Science, 201: 628 (1978).

60. Engle, M. A., Lewy, J. E., Lewy, P. R., and Metcoff, J.: The use of furosemide in the treatment of edema in infants and children. Pediatrics, 62: 811 (1978).

61. Fitzhardinge, P. M., Pape, K., Arstikaitis, M., Boyle, M., Ashby, S., Bowley, A., Netley, C., and Swyer, P. R.: Mechanical ventilation of infants less that $1,501 \mathrm{gm}$ birth weight: health, growth and neurologic sequelae. J. Pediatr., 88: 531 (1976).

62. Fox, I. H., Andres, C. M., Gelfand, E. W., and Biggar, D.: Purine nucleoside phosphorylase deficiency: altered kinetic properties of a mutant enzyme. Science, 197: 1084 (1977).

63. Friedland, G. W., Dodds, W. J., Sunshine, P., and Zboralske, F. F.: The apparent disparity in incidence of hiatal hernia in infants and children in Britain and the United States. Am. J. Roentgenol. Radium Ther. Nucl. Med., /20: 305 (1974). 
64. Friedland, G. W., Sunshine, P.. and Zboralske, F. F.: Hiatal hernia in infants and young children: a 2- to 3 -year follow-up study. J. Pediatr., 87: 71 (1975).

65. Froese, A. and Bryan. A. C.: Ventilation by high frequency ossilatorpreliminary report. In: L. Stern, B. Sale, and B. Friis-Hansen: Intensive Care in the Newborn. Vol. 3. pp. 271-273 (Massan Publishing Co.. New York, 1981).

66 Gaull, G. E., Rassin, D. K.. Räihä, N. C. R., and Heinonen, K.: Milk protein quantity and quality in low-birth-weight infants. III. Effects on sulfur amino acids in plasma and urine. J. Pediatr., 90: 348 (1977).

67. Gaull, G., Sturman, J. A., and Schaffner, F.: Homocystinuria due to cystathionine synthase deficiency: enzymatic and ultrastructural studies. J. Pediatr. 84: 381 (1974)

68. Gluck, L. and Kulovich, M. V.: Fetal lung development: current concepts. Pediatr. Clin. N. Am., 20:367 (1973)

69. Gluck, L., Julovich, M. V., Borer, R. C., Jr., Brenner, P. H., Anderson, G. G., and Spellacy, W. N.: Diagnosis of the respiratory distress syndrome by aminocentesis. Am. J. Obstet. Gynecol., 109:440 (1971).

70. Goldman, A. S. and Smith, C. W.: Host resistance factors in human milk. J. Pediatr. 82: 1082 (1973).

71. Green, F. R., Ho. M., Dodson, D., and Tsang, R. C.: Lack of 25-hydroxyvitamin D and 1,25-dihydroxyvitamin D in human milk. J. Pediatr., 99: 233 (1981).

72. Gross, T. L., Sokol, R. J., Wilson, M. V., Kuhnert, P. M., and Hirsch. V Amniotic fluid phosphatidylglycerol: a potentially useful predictor of intrauterine growth retardation. Am. J. Obstet. Gynecol., 140: 277 (1981).

73. Hack, M.. Fanaroff, A. A., and Merkatz, I. R.: The low-birth-weight infant evolution of a changing outlook. N. Engl. J. Med., 301: 1162 (1979).

74. Hagberg, F.: Epidemiological and preventive aspects of cerebral palsy and severe mental retardation in Sweden. Eur. J. Pediatr.. 130: 71 (1979).

75. Herbst, J. J.. Johnson, D. G., and Oliveros. M. A.: Gastroesophageal reflux with protein-losing enteropathy and finger clubbing. Am. J. Dis. Child. 130: $1256(1978)$

76. Herbst, J. J., Menton, D. S., and Book, L. S.: Gastroesophageal reflux causing respiratory distress and apnea in newborn infants. J. Pediatr., 95: 763 (1979).

77. Hertz, R. H., Sokol, R. J., Knoke, J. D., Rosen, M. G., Chik, L., and Hirsch, B. S.: Clinical estimation of gestational age: rules for avoiding preterm delivery. Am. J. Obstet. Gynecol., 131: 395 (1978).

78. Hitner, H. M., Godio, L. B., Rudolph, A. J., Adams, J. M., Garcia-Prats, J. A. Friedman, Z., Kautz, J. A., and Monaco, W. A.: Retrolental fibroplasia: efficacy of vitamin $E$ in a double-bind clinical study of preterm infants. $N$. Engl. J. Med., 305: 1365 (1981).

79. Francke, U., Felsenstein, J., Gartler, S. M., Migeon, B. R., Dancis, J.. Seegmiller, J. E., Bakay, F., and Nyhan. W. L.: The occurrence of new mutants in the $X$-linked recessive Lesch-Nyhan disease. Am. J. Hum. Genet., 28: 123 (1976).

80. Freinkel, N. and Metzger, G. E.: Pregnancy as a tissue culture experience: the critical implications of maternal metabolism for fetal development. In: Pregnancy Metabolism, Diabetes and the Fetus. CIBA Foundation Symposium \#63. pp. 3-28. (Excerpta Medica, Amsterdam, 1979).

81. Giardina, A. C. V., Ehlers, K. H., Morrison, J. B., and Engle, M. A.: Serum digitoxin concentrations in infants and children. Circulation, 51: 713 (1975).

82. Goetzman, B. W., Sunshine, P., Johnson, J. D., Wennberg, R. P., Hackel, A., Merten. D. F.. Bartoletti, A. L., and Silverman, N. H.: Neonatal hypoxia and pulmonary vasospasm: response to tolazoline. J. Pediatr., 89: 617 (1976).

83. Goldstein, A. S., Hoogenraad, N. J., Johnson, J. D., Fukanaga, K., Swierczewski, E.. Conn, H. M., and Sunshine, P.: Metabolic and genetic studies of a family with ornithine transcarbamylase deficiency. Pediatr. Res., $8: 5$ (1974).

84. Gutai, J. P., Kowarski, A. A., and Migeon, C. J.: The detection of the heterozygous carrier for congenital virilizing adrenal hyperplasia. J. Pediatr. 90: 924 (1977).

85. Hall, R. Smith, P. A., Harkness, R. A., and Smart, G. A.: A study of the parents of patients with congenital adrenal hyperplasia: detection of the heterozygote. Proc. Roy. Soc. Med., 63: 1040 (1970).

86. Hobbins, J. C., Mahoney, M. J., and Goldstein, L. A.: New method of intrauterine evaluation by the combined use of fetoscopy and ultrasound. Am. J. Obstet. Gynecol., 118: 1069 (1974).

87. Homoki. J., Fazekas, A. T. A., and Teller, W. M.: Urinary excretion of pregnanetriolone in parents of children with 21-hydroxylase deficiency before and after stimulation with adrenocorticotropic hormone. In: P. A Lee, L. P. Plotnick. A. A. Kowarski and C. J. Migeon: Congenital Adrenal Hyperplasia. pp. 479-485 (University Park Press, Baltimore, 1977).

88. Horwitz, A. L. and Dorfman, A.: The enzymic defect on Morquio's disease: the specificity of $\mathrm{N}$-acetylhexosamine sulfatase. Biochem. Biophys. Res. Commun., 80: 819 (1978)

89. Ikegami, M., Jobe, A., and Glatz. T.: Surface activity following natural surfactant treatment in premature lambs. J. Appl. Physiol.. 51: 306 (1981)

90. Johnson, D. G., Herbst, J. J., Oliveros, M. A., and Stewart, D. R.: Evaluation of gastroesophageal reflux surgery in children. Pediatrics, 59: 62 (1977).

91. Johnson, J. D., Albritton, W. L.. and Sunshine, P.: Hyperammonemia accompanying parenteral nutrition in newborn infants. J. Pediatr., 81: 154 (1972)

92. Johnson, J. D. Malachowski, N. C., Grobstein, R., Welsh, D., Daily, W. J R., and Surshine, P.: Prognosis of children surviving with the aid of mechanical ventilation in the newborn period. J. Pediatr., 84: 272 (1974).
93. Kapoor N. O’Reilly, R. J., Kirkpatrick, D., Pollack, M. S., Dupont, B., Good, R. A., and Reisner, Y.: Restoration of immunological function by a histo-incompatible. $\Upsilon$ cell depleted marrow transplant in a child with severe combined immunodeficiency. Pediatrics (abstract), 16:224A (1982).

94. Kaufman, S. Berlow, S.. Summer, G. K.. Milstein, S., Schulman. J. D., Orloff, S. Spiclberg, S.. and Pueschel, S.: Hyperphenylalaninemia due to a deficiency of biopterin. N. Engl. J. Med., 299:673 (1978).

95. Kaufman. S., Holtzman, N. A.. Milstein, S., Butler, I. J.. and Krumholz.. A.: Phenylketonuria due to deficiency of dihydropteridine reductase. N. Engl. J. Med., 293: 785 (1975).

96. Khazin, A. F and Hon. E. H.: Observations on fetal heart rate and fetal biochemistry. II. Fetal-material pH differences. Am. J. Obstet. Gynecol., 109: (1971).

97. Kimble K. J. Darnall, R. A., Jr.. Yelderman. M., Ariagno, R., and Ream, A. K. An automated oscillometric technique for estimating mean arterial pressure in critically ill newborns. Anesthesiology, 54: 423 (1981).

98. Knorr, D., Bidlingmaier, F., Butenandt, O., Schnakenburg. K. V., and Wagner, W.: Test for heterozygosity of congenital adrenal hyperplasia. In: P. A. Lee, L. P. Plotnick, A. A. Kowarski and C. J. Migeon: Congenital Adrenal Hyperplasia. pp. 495-500 (University Park Press. Baltimore, 1977).

99. Kohn, B., Levine, L. S., Pollack, M. S., Pang, S., Lorenzen, F., Levy, D. Lerner, A. J., Rondanini, G. F.. Dupont, B., and New, M. I.: Late-onset steroid 21 -hydroxylase deficiency: a variant of classical congenital adrenal hyperplasia. J. Clin. Endocrinol. Metab.. 55:817 (1982).

100. Komazawa. M., Landow, S. A., and Oski, F. A.: Lack of relationship of red cell enzyme activity to bilirubin and carboxyhemoglobin levels in healthy term infants. Acta Pacdiatr. Scand., 64: 473 (1975).

101. Koops, B. L and Harmon, R. J.: Studies on long-term outcome in newborns with birth weights under 1500 grams. Adv. Behav. Pediatr., l: 1 (1980).

102. Korth-Schutz, S., Levine, L. S.. and New, M. I.: Serum androgens in normal prepubertal and pubertal children and in children with precocious adrenarche. J. Clin. Endocrinol. Metab., 42: 117 (1976)

103. Krensky, A. M. Bongiovanni, A. M.. Marino, J., Parks. J., and Tenore. A.. Identification of heterozygote carriers of congenital adrenal hyperplasia by radioimmunoassay of serum 17-OH progesterone. J. Pediatr.. 90: 930 (1977).

104. Kuhnert, B. R., Knapp. D. R.. Kuhnert, P. M., and Prochaska. A. L. Maternal, fetal and neonatal metabolism of lidocaine. Clin. Pharmacol. Ther., 26: $213(1979)$

105. Kuhnert, B. R.. Kuhnert, P. M.. and Knapp, D. R.: Relationship between cord vein normeperidinc and time. Am. J. Obstet. Gynecol. (letter), 137: $518(1980)$

106. Kuhnert, B. R., Kuhnert, P. M., Prochaska, A. L., and Gross, T. L.: Plasma levels of 2-chloroprocaine in obstetric patients and their neonates after epidural anesthesia. Anesthesiology, 53: 21 (1980).

107. Kuhnert, B. R., Kuhnert, P. M., Tu, A-S. L., and Lin, D. C. K.: Meperidine and normeperidine levels following meperidine administration during labor. II. Fetus and neonate. Am. J. Obstet. Gynecol., 133: 909 (1979).

108. Kuhnert, B R Kuhnert, P. M. Tu, A-S. L., Lin, D. C. K., and Foltz, R. L.: Meperidine and normeperidine levels following meperidine administration during labor. I. Mother. Am. J. Obstet. Gynecol., 133: 904 (1979).

109. Kuhnert. P. M.. Erhard, P., Kuhnert. B. R., Sokol, R. J.. and Gross, T. L.: A modified lecithin/sphingomyelin ratio test for fetal maturity. Am. J. Obstet. Gynecol., 135: 331 (1979).

110. Kulovich, M. V., Hallman, M. B., and Gluck. L.: The lung profile. I. Normal pregnancy. Am. J. Obstet. Gynecol., 135: 57 (1979).

111. Krouskop, R. W., Brown, E. G.. and Sweet, A. Y.: The early use of continuous positive airway pressure in the treatment of idiopathic respiratory distress syndrome. J. Pediatr.. 87: 263 (1975).

112. La Du, B. M. and Gjessing, L. R.: Tyrosinosis and tyrosinemia. In: J. B. Stanbury, J. B. Wyngaarden, and D. S. Fredrickson: The Metabolic Basis of Inherited Disease. 4th ed. pp. 256-267 (McGraw Hill, New York, 1978).

13. Lee, P. A. and Gareis, F. J.: Evidence for partial 21 -hydroxylase deficiency among heterozygote carriers of congenital adrenal hyperplasia. J. Clin. Endocrinol. Metab., 41: 415 (1975).

14. Lesch, M. and Nyhan, W. L.: A familial disorder of uric acid metabolism and central nervous system function. Am. J. Med., 36: 561 (1964)

15. Levy, R. H., Klemperer, M. R., Gelfand, E. W., Sanderson, A. R., Batchelor, J. R. Berkel, A. I. and Rosen, F. S.: Bone-marrow transplantation in severe combined immunodeficiency syndrome. Lancet, 2: 571 (1971).

116. Levine, L. S., Dupont, B., Lorenzen, F., Pang, S., Pollack, M.. Oberficld, S.. Kohn, B., Lerner, A., Cacciari, E., Mantero. F., Cassio, A., Scaroni. C., Chiumello, G., Rondanini, G. F., Gargantini, L., Giovannelli, G., Virdis. R. Bartolotta, E Migliori, C. Pintor, C., Tato, L., Barboni, F., and New, M. 1.: Cryptic 21-hydroxylase deficiency in families of patients with classical congenital adrenal hyperplasia. J. Clin. Endocrinol. Metab., 51: 1316 (1980).

117. Levine, L. S., Dupont, B., Lorenzen, F., Pang, S., Pollack, M.. Oberfield, S. E. Kohn, B., Lerner, A., Cacciari, E., Mantero, F., Cassio. A., Scaroni, C., Chiumello. C. Rondanini, G. F.. Gargantini, L., Giovanneli, C., Virdis. R., Bartolotta, E., Migliori, C., Pintor, C., Tato, L., Barboni, F., and New, $M$. I.: Genetic and hormonal characterization of cryptic 21-hydroxylase deficiency. J. Clin. Endocrinol. Metab., 53: 1193 (1981).

118 Levine, L. S Zachmann, M. New, M. I., Prader, A., Pollack, M. S.. O'Neill, G. J Yano S. Y Oberfield, S. E., and Dupont, B.: Genetic mapping of the 21 -hydroxylase deficiency gene within the HLA linkage group. N. Engl. J. Med., 299: 911 (1978) 
119. Liebhaber, M., Lewiston, N. J., Asquith, M. T., Olds-Arroyo, L., and Sunshine, P.: Alterations of lymphocytes and of antibody content of human milk after processing. J. Pediatr., 91: 897 (1977).

120. Lorenzen, F.. Pang, S., New, M. I., Dupont, B., Pollack, M. S., Chow, D. M., and Levine, L. S.: Hormonal phenotype and HLA-genotype in families of patients with congenital adrenal hyperplasia (21-hydroxylase deficiency). Pediatr. Res., 13: 1356 (1979).

121. Lorenzen, F., Pang. S., New, M., Pollack, M., Oberfield, S., Dupont, B., Chow, D.. Schneider, B., and Levine, L.: Studies of the C-21 and C-19 steroids and HLA genotyping in siblings and parents of patients with congenital adrenal hyperplasia due to 21 -hydroxylase deficiency. J. Clin. Endocrinol. Metab.. 50: 572 (1980).

122. Lubchenco, L. O., Delivoria-Papadopoulos, M., and Searls, D.: Long-term follow-up studies of prematurely born infants. II. Influence of birth weight and gestational age on sequelae. J. Pediatr., 80:509 (1972).

123. Lubchenco, L O. Horner, F A Reed, L. H. Hix I. E Jr. Metcalf, D. Cohig. R., Elliott. H. C., and Bourg, M.: Sequelae of premature birth: evaluation of premature infants of low birth weights at ten years of age. Am. J. Dis. Child., 106: 101 (1963).

124. Mahoney, M. J. and Hobbins, J. C.: Ultrasound and growth of amniotic-fluid cells. Lancet, 2: 454 (1973)

125. Martin, R. J., Nearman. H. S., Katona, P. G., and Klaus, M. H.: The effect of low continuous positive airway pressure on the reflux control of respiration in the preterm infant. J. Pediatr., 90: 976 (1977).

126. Matalon, R., Arbogast, B., and Dorfman, A.: Deficiency of chondroitin sulfate- $\mathrm{N}$-acetylgalactosamine 4-sulfate in Maroteaux-Lamy syndrome. Biochem. Biophys. Res Commun 6I.1450 (1974).

127. Matalon, R., Arbogast. B., Justice. P., Brandt, I. K., and Dorfman, A.: Morquio's syndrome: deficiency of a chondroitin sulfate N-acetylhexosamine sulfate sulfatase. Biochem. Biophys. Res. Commun., 61: 759 (1974).

128. Matalon, R. and Dorfman, A.: Hurler's syndrome, an $\alpha$-I-iduronidase deficiency. Biochem. Biophys. Res. Commun. 47: 959 (1972).

129. Mathew, R. Thilenius, O. G., Replogle. R. L. and Arcilla, R. A.: Cardiac function in total anomalous pulmonary venous return before and after surgery. Circulation, 55: 361 (1977)

130. Mease, P. J., Ochs, H. D., and Wedgwood, R. J.: Successful treatment of echovirus meningoencephalitis and myositis-fasciitis with intravenous immune globulin therapy in a patient with $\mathrm{X}$-linked agammaglobulinemia. N. Engl. J. Med.. 304: 1278 (1981)

131. Metzger, B. E.. Phelps, R. L., Freinkel, N., and Navickas, I. A.: Effects of gestational diabetes on diurnal profiles of plasma glucose, lipids and individual amino acids. Diabetes Care, 3: 402 (1980).

132. Meuwissen, H. J. Pickering. R. J Moore, E. C. and Pollara, B.: Impairment of adenosine deaminase activity in combined immunological deficiency disease. In: H. J. Meuwissen, B. Pollara, R. J. Pickering, and I. A. Porter: Combined Immunodeficiency Disease and Adenosine Deaminase Deficiency. pp. 73-83 (Academic Press. New York, 1975).

133. Mitchell, B. S. Mejias, E.. Daddonna, P. E.. and Kelley, W. N. Purinogenic immunodeficiency diseases: selective toxicity of deoxyribonucleosides for T cells. Proc. Nat1. Acad. Sci. USA, 75: 5011 (1978).

134. Morrow, G.. III, Barness, L. A.. Cardinale, G. J., Abeles, R. H., and Flaks, J. $\mathrm{G}$ : Congenital methylmalonic acidemia: enzymatic evidence for two forms of the disease. Proc. Natl. Acad. Sci. USA.. 63:191 (1969).

135. Nakamura, J. and Roux, J. F.: Determination of amniotic fluid phospholipids for the diagnosis of fetal maturation. Am. J. Obstet. Gynecol., 119: 104 (1974).

136. Nakamura, J., Roux, J. F., Brown, E. G., and Sweet, A. Y.: Total lipids and the lecithinsphingomyelin ratio of amniotic fluid: an antenatal test of lung immaturity? Am. J. Obstet. Gynecol., 113: 363 (1972).

137. Neuman. M. R.. Critchfield. F. H., and Lin. W. C.: An intravaginal fetal ECG telemetry system. Obstet. Gynecol., 35:96 (1970).

138. Neuman, M. R., Picconnatto, J., and Roux, J. F.: A wireless radiotelemetry system for monitoring fetal heart rate and intrauterine pressure during labor and delivery. Gynecol. Invest.. 1: 92 (1970).

139. Neuman, M. R., Roux, J. F., Patrick. J. E., Munro, M. G.. Cudmore. D. W. Owen. S. M. Angel, E., Fox. H. E., and Pessel, D.: Evaluation of fetal monitoring by telemetry. Obstet. Gynecol., 54: 249 (1979).

140. New, M. I., Dupont, B., Lorenzen, F., Pang, S., Pollack, M. S.. Oberfield, S. E., Kohn. B., Lerner. A. J., Cacciari, E., Mantero, F., Cassio, A., Scaroni, C. Chiumello, G., Rondanini, G. F. Gargantini, L. Giovannelli, G. Virdis, R., Bartolotta. E., Migfliori, C.. Pintor, C., Tato, L., Barboni, C., and Levine, L. S.: Recognition of allelic variants of 21 -hydroxylase deficiency by HLA genotyping: hormonal and clinical evaluation. In: $G$. Chiumello and M. Sperling: Recent Progress in Pediatric Endocrinology, Serono Series. Milan. October 22-23, 1981. pp. 183-219 (Raven Press. New York. 1983)

141. New, M. I., Dupont, B., Pang, S., Pollack, M., and Levine, L. S.: An update of congenital adrenal hyperplasia. Recent Prog. Horm. Res., 37: 105 (1981).

142. New, M. I.. Dupont, B., Pollack, M. S., and Levine, L. S.: The biochemical basis for genotyping 21-hydroxylase deficiency. Hum. Genet., 58: 123 (1981).

143. New, M. I., Grumbach, K., and Levine, L. S.: Disorders of the adrenal gland. In: A. E. H. Emery and D. L. Rimoin: The Principles and Practice of Medical Genetics. (Churchill Livingston. Inc., New York, in press).

144. Nolte, M. T.. Pirofsky, B., Gerritz. G. S.. and Golding, B.: Intravenous immunoglobulin therapy for antibody deficiency. Clin. Exp. Immunol. $36: 237(1979)$

145. Northway, W. H., Jr.: Observations on bronchopulmonary dysplasia. J. Pediatr. 95: 815 (1979).
146. Northway, W. H., Jr. and Rosan, R. C.: Radiographic features of pulmonary oxygen toxicity in the newborn: bronchopulmonary dysplasia. Radiology, 91: 49 (1968).

147. Northway, W. H., Jr., Rosan, R. C., and Porter, D. Y.: Pulmonary disease following respirator therapy of hyaline-membrane disease: bronchopulmonary dysplasia. N. Engl. J. Med., 276: 357 (1967).

148. Ochs, H. D., Buckley, R. H., Pirofsky, B., Fischer, S. H., Rousell, R. H. Anderson, C. J.. and Wedgwood, R. J.: Safety and patient acceptability of intravenous immune globulin in 10\% maltose. Lancet, 2: $1158(1980)$.

149. Ogata, E. S., Freinkel, N., Metzger, B. E., Phelps, R. L., Depp, R., Boehm, J. J., and Dooley, S. L.: Perinatal islet function in gestational diabetes: assessment by cord plasma c-peptide and amniotic fluid insulin. Diabetes Care, 3: 425 (1980).

150. Ogata, E. S., Sabbagha, R., Metzger, B. E., Phelps, R. L., Depp, R., and Freinkel, N.: Serial ultrasonography to assess evolving fetal macrosomia: studies in 23 pregnant diabetic women. J. Am. Med. Assoc., 243: 2405 (1980).

151. O'Gureck. J. E., Roux, J. F., and Neuman, M. R.: Neonatal depression and fetal heart rate patterns during labor. Obstet. Gynecol, 40: 347 (1972).

152. O'Gureck, J. E., Roux, J. F., and Neuman, M. R.: A practical classification of fetal heart rate patterns. Obstet. Gynecol., 40:356 (1972).

153. O'Neill, G. I., Dupont, B., Pollack, M. S., Levine, L. S., and New, M. I. Complement $C 4$ allotypes in congenital adrenal hyperplasia due to 21 hydroxylase deficiency: further evidence for different allelic variants at the 21-hydroxylase locus. Clin. Immunol. Immunopathol., 23: 312 (1982).

154. Oski, F. A.: Red cell metabolism in the premature infant. II. The pentose phosphate pathway. Pediatrics, 39: 689 (1967).

155. Oski, F. A. and Barness, L. A.: Vitamin E deficiency: a previously unrecognized cause of hemolytic anemia in the premature infant. J. Pediatr., 70 211 (1967).

156. Oski, F. A. Grottlieb, A. J. Miller, W. W, and Delivoria-Papadopoulos, M The effects of deoxygenation of adult and fetal hemoglobin on the synthesis of red cell 2,3-diphosphoglycerate and its in vivo consequences. J. Clin. Invest., 49: 400 (1970).

157. Outerbridge, E. W.. Ramsey, M., and Stern, L.: Developmental follow-up of survivors of neonatal respiratory failure. Crit. Care Med., 2: 23 (1974)

158. Overall, J. C.. Jr.: Viral infections of the fetus and neonate. In: R. D. Feigin and J. D. Cherry: Textbook of Pediatric Infectious Diseases. pp 684-721 (W. B. Saunders Co., Philadelphia, 1981)

159. Pagliara, A. S., Karl, I. E., De Vivo, D. C., Feigin, R. D., and Kipnis, D. M. Hypoalaninemia: a concomitant of ketotic hypoglycemia. J. Clin. Invest. 5I:1440 (1972).

160. Pagliara, A. S., Karl, 1. E., Keating, J. P., Brown, B. I., and Kipnis, D. M.: Hepatic fructose-1,6-diphosphatase deficiency: a cause of lactic acidosis and hypoglycemia in infancy. J. Clin. Invest., S1:2115 (1972).

161. Pang, S., Hotchkiss, J., Drash, A. L.. Levine. L. S., and New, M. I.: Microfilter paper method for $17 \alpha$-hydroxyprogesterone radioimmunoassay: its application for rapid screening for congenital adrenal hyperplasia. J. Clin. Endocrinol. Metab., 45: 1003 (1977).

162. Pang. W., Levine, L. S., Cederquist, L. L., Fuentes, M., Riccardi, V. M. Holcombe. J. H., Nitowsky, H. M. Sachs, G., Anderson, C. E., Duchon. M. A., Owens, R., Merkatz, I., and New, M. I.: Amniotic fluid concentrations of $\Delta-5$ and $\Delta-4$ steroids in fetuses with congenital adrenal hyperplasia due to 21-hydroxylase deficiency and in anencephalic fetuses. J. Clin. Endocrinol. Metab., 51: 223 (1980).

163. Pang, S., Levine, L. S., Chow, D. M., Faiman, C.. and New, M. 1.: Serum androgen concentrations in neonates and young infants with congenital adrenal hyperplasia due to 21-hydroxylase deficiency. Clin. Endocrinol. (Oxford), 11: 575 (1979).

164. Pang, S., Levine, L. S., Chow, D., Sagiani, F., Saenger, P., and New, M. I.: Dihydrotestosterone and its relationship to testosterone in infancy and childhood. J. Clin. Endocrinol. Metab., 48: 821 (1979).

165. Pang. S. Murphy, W. Levine, L. S. Spence, D., Leon, A., LaFranchi, S. Surve, A., and New, M. 1.: A pilot newborn screening for congenital adrenal hyperplasia $(\mathrm{CAH})$ at New York Hospital (NYH) and Alaska. Pediatr. Res. (abstract), 15: 512/435 (1981).

166. Pang, S., Murphey, W., Levine, L. S., Spence, D. A., Leon, A., LaFranchi, S. Surve. A. S., and New, M. I.: A pilot newborn screening for congenital adrenal hyperplasia in Alaska. Clin. Endo. Metab., 55: 413 (1982).

167. Pape, K. E., Buncic, R. J., Ashby. S., and Fitzhardinge, P. M.: The status at two years of low-birth-weight infants born in 1974 with birth weights of less than 1,001 g. J. Pediatr. 92:253 (1978).

168. Parkman. R., Rappeport. J., Geha, R., Belli, J., Cassady, R.. Levey, R., Nathan, D. G., and Rosen, F. S.: Complete correction of the WiskottAldrich syndrome by allogeneic bone-marrow transplantation. N. Engl. J. Med.. 298: 921 (1978).

169. Pass, M. A., Johnson, J. D., Schulman, I. A., Grumet, C. F., Hafleigh, E. B. Malachowski, N. C., and Sunshine, P.: Evaluation of walking-donor transfusion program in an intensive care nursery. J. Pediatr.. 89: 646 (1976).

170. Pellegrini, C. A., DeMeester, T. R., Johnson, L. F., and Skinner, D. B. Gastroesophageal reflux and pulmonary aspiration: incidence, functional abnormality, and results of surgical therapy. Surgery, 86: 110 (1979).

171. Perlstein. P. H., Hersh, C., Glueck. C. J., and Sutherland, J. M.: Adaptation to cold in the first three days of life. Pediatrics, 54:411 (1974).

172. Peterson, C. M., Kalan, G., Jovanovic, L., and Jovanovic, R.: Use of the minor hemoglobin ratio for the determination of gestational age. Am. J. Obstet. Gynecol.. 135: 85 (1979)

173. Pollack, M. S., Levine, L. S., O'Neill, G. J., Pang, S., Lorenzen, F., Kohn, B. Rondanini, G. F.. Chiumello, G., New, M. I.. and Dupont, B.: HLA linkage 
and $\mathrm{B} 14, \mathrm{DR} 1, \mathrm{~B} / \mathrm{S}$ haplotype association with genes for late onset and cryptic 21 -hydroxylase deficiency. Am. J. Hum. Genet., 33: 540 (1981).

174. Pollack, M. S., Maurer, D., Levine, L. S., New, M. I., Pang, S., Duchon, M. A. Owens, R. P., Merkatz, I. R., Nitowsky, H. M., Sachs, G., and Dupont, B. HLA typing of amniotic cells: the prenatal diagnosis of congenital adrenal hyperplasia (21-OH-deficiency type). Transplant Proc., 11: 1726 adrenal
(1979).

175. Pollack, M. S., Maurer, D., Levine, L. S., New, M. I., Pang, S., Duchon, M. Owens, R. P., Merkatz, I. R., Nitowsky, H. M., Sachs, G., and Dupont, B.: Prenatal diagnosis of congenital adrenal hyperplasia (21-hydroxylase deficiency) by HLA typing. Lancet, $l: 1107$ (1979).

176. Polmar, S. H., Stern, R. C., Schwartz, A. L., Wetzler, E. M., Chase, P. A. and Hirschhorn, R.: Enzyme replacement therapy for adenosine deaminase deficiency and severe combined immunodeficiency. N. Engl. J. Med., 295 1337 (1976).

177. Prescott, L. G., Park, J., Ballantyne, A., Adriaenssens, P., and Proudfoot, A $\mathrm{T}$.: Treatment of paracetamol (acetaminophen) poisoning with $\mathrm{N}$-acetylcysteine. Lancet, 2: 432 (1977)

178. Qazi, Q. H. Hill, J. G., and Thompson, M. W.: Steroid studies in parents of patients with congenital virilizing adrenal hyperplasia. J. Clin. Endocrinol. Metab., 33: 23 (1971)

179. Räihä, N. C. R., Heinonen, K., Rassin, D. K., and Gaull, G. E.: Milk protein quantity and quality in low-birth-weight infants. I. Metabolic responses and effects on growth. Pediatrics, 57: 659 (1976).

180. Rassin, D. K. Gaull, G. E., Heinonen, K., and Räihä, N. C. R.: Milk protein quantity and quality in low-birth-weight infants. II. Effects on selected aliphatic amino acids in plasma and urine. Pediatrics, 59: 407 (1977).

181. Rassin, D. K., Gaull, G. E., Räihä, N. C. R., and Heinonen, K.: Milk protein quantity and quality in low-birth-weight infants. IV. Effects on tyrosine and phenylalanine in plasma and urine. J. Pediatr., 90:356 (1977)

182. Rassin, D. K.. Longhi, R. C., and Gaull, G. E.: Free amino acids in liver of patients with homocystinuria due to cystathionine synthase deficiency: effects of vitamin $B_{6}$. J. Pediatr., 91: 574 (1977).

183. Rassin. D. K., Longhi, R. C., Sternowsky, H. J., Sturman, J. A., and Gaull, G. E.: Homocysteine and cysteine loads in patients with homocystinuria due to cystathione synthetase deficiency: effects of vitamin $\mathrm{B}_{6}$. Clin. Chim. Acta, 79: 197 (1977).

184. Rawlings, G., Reynolds, E. O. R., Steward, A., and Strang, L. B.: Changing prognosis for infants of very low birth weight. Lancet, $l: 516$ (1971).

185 Reinherz, E. L.. Geha, R., Rappeport, J. M., Wilson, M., Penta, A. C., Hussey, R. E. Fitzgerald, K. A., Daley, J. F., Levine, H., Rosen, F. S., and Schlossman. S. F.: Reconstitution after transplantation with T-lymphocytedepleted HLA haplotype-mismatched bone marrow for severe combined immunodeficiency. Proc. Natl. Acad. Sci., USA, 79: 6047 (1982).

186. Reynolds, D. W., Stagno, S., Herrman, K. L., and Alford, C. A.: Antibody response to live virus vaccines in congenital and neonatal cytomegalovirus infections. J. Pediatr., 92: 738 (1978).

187. Reynolds, D. W., Stagno, S., Stubbs, K. G., Dahle, A. J., Livingston, M. M Saxon. S. S., and Alford, C. A.: Inapparent congenital cytomegalovirus infection with elevated cord IgM levels: causal relation with auditory and mental deficiency. N. Engl. J. Med. 290: 291 (1974).

188. Reynolds, E. O. R. and Taghizadeh, A.: Improved prognosis of infants mechanically ventilated for hyaline membrane disease. Arch. Dis. Child., 49.505 (1974).

189. Rigg, L. Cousins, L., Hollingsworth, D., Brink, G., and Yen, S. S. C.: Effects of exogenous insulin on excursions and diurnal rhythm of plasma glucose in pregnant diabetic patients with and without residual beta-cell function. Am. J. Obstet. Gynecol., 136: 537 (1980).

190. Rosen, M. G., Sokol, R. J., and Chik, L.: Use of computers in the labor and delivery suite: an overview, Am. J. Obstet. Gynecol., 132: 589 (1978).

191. Rosenberg, L. E., Lilljeqvist, A. C., and Hsia, Y. E.: Methylmalonic aciduria: an inborn error leading to metabolic acidosis, long-chain ketonuria and intermittent hyperglycemia. N. Engl. J. Med., 278: 1319 (1968)

192. Rösler, A., Levine, L. S., Schneider, B., Novogroder, M., and New, M. I.: The interrelationship of sodium balance, plasma renin activity and $\mathrm{ACTH}$ in congenital adrenal hyperplasia. J. Clin. Endocrinol. Metab., 45: 500 (1977).

193. Roux, H., Loras, B., and Forest, M. G.: Congenital adrenal hyperplasia caused by 21 -hydroxylase deficiency plasma $17 \alpha$-hydroxyprogesterone in patients' relatives In: P. A Lee L. P. Plotnick, A. A. Kowarski, and C. J. Migeon: Congenital Adrenal Hyperplasia. pp. 487-493 (University Park Press, Baltimore, 1977).

194. Roux, J. F., Grigorian, A., and Takeda, Y.: In vitro "lipid" metabolism in the developing human foetus. Nature (London), 216: 819 (1967).

195. Roux, J. F Nakamura, J., and Brown, E. G.: Further observations on the determination of gestational age by amniotic fluid analysis. Am. J. Obstet. Gynecol., 116: 633 (1973).

196. Roux, J. F., Neuman, M. R., and O'Gureck, J. E.: The value and limitations of fetal monitoring by transvaginal telemetry and conventional wire systems. Int. J. Gynaecol. Obstet., 10: 199 (1972).

197. Roux, J. R., Takeda, Y., and Grigorian, A.: Lipid concentration and composition in human fetal tissue during development. Pediatrics, 48: 540 (1971).

198. Sandman, R., Ammann, A. J., Grose, C., and Wara, D. W.: Cellular immunodeficiency associated with nucleoside phosphorylase deficiency: immunologic and biochemical studies. Clin. Immunol. Immunopathol., 8: 247 (1977).

199. Schmalstieg, F. C., Mills, G. C., Nelson, J. A., May, L. T., Goldman, A. S. and Goldblum, R. M.: Limited effect of erythrocyte and plasma infusions in adenosine deaminase deficiency. J. Pediatr., 93: 597 (1978).
200. Shahinian, L., Jr. and Malachowski, N.: Retrolental fibroplasia: a new analysis of risk factors based on recent cases. Arch. Ophthalmol., 96: 70 (1978).

201. Short, E. M., Conn, H. O., Snodgrass, P. J., Campbell, A. G. M., and Rosenberg, L. E.: Evidence for X-linked inheritance of ornithine transcarbamylase deficiency. N. Engl. J. Med., 288: 7 (1973).

202. Sjörberg, I. Fransson, L-A. Matalon, R., and Dorfman, A.: Hunter's syndrome: a deficiency of L-idurono-sulfate sulfatase. Biochem. Biophys. Res. Commun., 54: 1125 (1973).

203. Smith, P. C., Daily, W. J. R., Fletcher, G., Meyer, H. B. P., and Taylor, G.: Mechanical ventilation of newborn infants. $I$. The effect of rate and pressure on arterial oxygenation of infants with respiratory distress syndrome. Pediatr. Res., 3: 244 (1969).

204. Sokol, R. J., Miller, S. I., and Reed, G.: Alcohol abuse during pregnancy: an epidemiologic study. Alcoholism (New York), 4: 135 (1980).

205. Sokol, R. J., Nussbaum, R. S., Chik, L., and Rosen, M. G.: Computer diagnosis of labor progression: IV. An on-line interactive digital computer subroutine for evaluating descent of the fetal presenting part during labor. J. Reprod. Med., I3: 177 (1974).

206. Sokol, R. J., Nussbaum, R. S., Chik, L., and Rosen, M. G.: Computer diagnosis of labor progression: $V$. Reliability of subroutine for evaluating station and descent of the fetal presenting part. J. Reprod. Med., 13:183 (1974).

207. Sokol, R. J., Rosen, M. G., Borgstedt, A. D., Lawrence, R. A., and Steinbrecher, M.: Abnormal electrical activity of the fetal brain and seizures of the infant. Am. J. Dis. Child., 127: 477 (1974).

208. Sokol, R. J., Rosen, M. G., Bottoms, S. F., and Chik, L.: Risks preceding increased primary cesarean birth rates. Obstet. Gynecol., 59: 340, (1982).

209. Ssokol, R. J., Rosen, M. G., Stojkov, J., and Chik, L.: Clinical application of high-risk scoring on an obstetric service. Am. J. Obstet. Gynecol., 128: 652 (1977).

210. Sokol, R. J., Stojkov, J., Chik, L., and Rosen, M. G.: Normal and abnormal labor progress: I. A quantitative assessment and survey of the literaturc. $J$. Reprod. Med. 18: 47 (1977).

211. Sokol, R. J., Woolf, R. B., Rosen. M. G., and Weingarden, K.: Risk, antepartum care and outcome: impact of a maternity and infant care project. Obstet. Gynecol., 56: 150 (1980).

212. Sokol. R. J., Zador, I., Rosen. M. G.: Slowing of active labor associated with internal fetal monitoring. Am. J. Obstet. Gynecol.. 124: 764 (1976).

213. Stagno, S., Pass, R. F., Dworsky, M. E., Henderson, R. E., Moore, E. G. Walton, P. D., and Alford, C. A.: Congenital cytomegalovirus infection: the relative importance of primary and recurrent maternal infection. $\mathrm{N}$. Engl. J. Med., 306: 945 (1982).

214. Stagno, S., Pass, R. F., Reynolds, D. W., Moore, M. A., Nahmias, A. J., and Alford, C. A.: Comparative study of diagnostic procedures for congenital cytomegalovirus infection. Pediatrics, 65: 251 (1980).

215. Stagno, S. Reynolds, D. W.. Huang, E-S., Thames, S. D., Smith, R. J., and Alford, C. A.. Jr.: Congenital cytomegalovirus infection: occurrence in an immune population. N. Engl. J. Med., 296: 1254 (1977).

216. Stahlman, M. T., Malan, A. F., Shepard, F. M., Blankenship, J. J., Young, W. C., and Gray, J.: Negative pressure assisted ventilation in infants with hyaline membrane disease. J. Pediatr., 76: 174 (1970)

217 Stanley, C. A. Anday, E. K., Baker, L., and Delivoria-Papadopolous. M.: Metabolic fuel and hormone responses to fasting in newborn infants. Pediatrics, 64: 613 (1979)

218. Steichen, J. J.. Tsang, R. C., Greer, F. R., Ho, M., and Hug, G.: Elevated serum 1,25-dihydroxyvitamin D concentrations in rickets of very lowbirth-weight infants. J. Pediatr., 99: 293 (1981)

219. Stevenson, D. K., Bartoletti, A. L., Ostrander, C. R., and Johnson, J. D.: Pulmonary excretion of carbon monoxide in the human infant as an index of bilirubin production. II. Infants of diabetic mothers. J. Pediatr., 94: 956 (1979).

220. Stevenson, D. K., Kasting. D. S., Darnall, R. A. Jr., Ariagno, R. L., Johnson, J. D., Malachowski, N., Beets, C. L., and Sunshine, P.: Refractory hypoxemia associated with neonatal pulmonary disease: the use and limitations of tolazoline. J. Pediatr. 95: 595 (1979).

221. Stoner, E., Starkman, H.. Wellner, D., Wellner, V. P., Sassa, S., Riskind, A. B., Grenier, A., Stienberg, P. G., Meister, A., New, M. I., and Levine, L. S.: Studies of a patient with hereditary hepatorenal tyrosinemia: evidence of glutathione deficiency. (Submitted Pediatr. Res.)

222. Sturman, J. A., Gaull, G., and Raiha, N. C. R.: Absence of cystathionase in human fetal liver: is cystine essential? Science, 169: 74 (1970).

223. Sweetman, L. Hoch, M. A., Bakay, B. Borden, M., Lesh, P., and Nyhan, W L.: A distinct human variant of hypoxanthine-guanine. phosphoribosyl transferase. J. Pediatr.. 92: 385 (1978).

224. Talner, N. S., Sanyal, S. K., Halloran, K. H., Gardner, T. H., and Ordway, $\mathrm{N} . \mathrm{K}$. Congestive heart failure in infancy. I. Abnormalities in blood gases and acid-base equilibrium. Pediatrics, 35: 20 (1965).

225. Thomas, D. V., Fletcher, G., Sunshine. P., Schafer, I. A., and Klaus, M. H. Prolonged respirator use in pulmonary insufficiency of newborn. J. Am. Med. Assoc., 193:183 (1965).

226. Timor-Tritsch, I. E., Dierker, L. J., Hertz, R. H., Deagan, N. C., and Rosen M. G.: Studies of antepartum behavioral state in the human fetus at term. Am. J. Obstet. Gynecol., 132: 524 (1978).

227. Timor-Tritsch, I. E., Dierker, L. J., Zador, I., Hertz, R. H., and Rosen, M. G.: Fetal movements associated with fetal heart rate accelerations and decelerations. Am. J. Obstet. Gynecol., I31: 276 (1978).

228. Timor-Tritsch, I., Zador, I., Hertz, R. H., and Rosen, M. G.: Classification of human fetal movement. Am. J. Obstet. Gynecol., 126: 70 (1976).

229. Timor-Tritsch, I., Zador. I., Hertz, R. H., and Rosen, M. G.: Human fetal 
respiratory arrhythmia. Am. J. Obstet. Gynecol., 127:662 (1977).

230. Tang, R. C., Chen, I-W., McEnery, P., Brown, D. R., Johnson, R., and Lesnicwicz, J.: Parathyroid function tests with EDTA infusions in infancy and childhood. J. Pediatr. 88: 250 (1976).

231. Wara, D. W. and Ammann. A. J.: Thymosin treatment of children with primary immunodeficiency disease. Transplant. Proc. 10.203 (1978).

232. Weinberg. A. G. Mize, C. E., and Worthen, H. G.: The occurrence of hepatoma in the chronic form of hereditary tyrosinemia. J. Pediatr., 88 : $434(1976)$.

233. Whaun. J. M, and Oski. F. A.: Relation of red blood cell glutathione peroxidase to neonatal jaundice. J. Pediatr., 76: 555 (1970).

234. Whitley, R. J. Nahmias, A. J. Visintine, A. M. Flemming, C. L., Alford, C. A., and the Collaborative Antiviral Study Group of the National Institute of Allergy and Infectious Disease: The natural history of herpes simplex virus infection of mother and newborn. Pediatrics, 66: 489 (1980).

235. Williams, P. R. Fiser, R. H J J. Sperling, M. A. and Oh, W.: Effects of oral alanine feeding on blood glucose, plasma glucagon and insulin concentrations in small-for-gestational age infants. N. Engl. J. Med., 292:612 (1975).

236. Williamson, A. P., Montgomery, J. R.. South, M. A., and Wilson, R.: A special report: four-year study of a boy with combined immune deficiency maintained in strict reverse isolation from birth. Pediatr. Res., 11: 63 (1977).

237. Wilmore, D. W. and Dudrick, S. J.: Growth and development of an infant receiving all nutrients exclusively by vein. J. Am. Med. Assoc., 203: 860 (1968).
238. World Health Organization. Report on Social and Biological Effects on Perinatal Mortality. Vol. 1 (World Health Organization. New York, 1978).

239. Yakovac, W. C., Baker, L., and Hummeler, K.: Beta cell nesidioblastosis in idiopathic hypoglycemia of infancy. J. Pediatr., 79: 226 (1971)

240. Yang, S. Y., Levine, L. S., Zachmann, M., New, M. I., Prader, A., Oberfield, S. E., O'Neill, G. J., Pollack, M. S., and Dupont, B.: Mapping of the 21 hydroxylase deficiency gene within the HLA linkage group. Transplant Proc. 10: 753 (1978).

241. Yeager, A. S., Grumet, F. C., Hafleigh, E. B., Arvin, A. M., Bradley, J. S. and Prober, C. G.: Prevention of transfusion-acquired cytomegalovirus infections in newborn infants. J. Pediatr., 98: 281 (1981).

242. Yoshioka T and Roux, J. F.: In vitro metabolism of palmitic acid in human fetal tissue. Pediatr. Res., 6: 675 (1972).

243. Zarin-Ackerman, J., Lewis, M., and Driscoll, J. M., Jr.: Language development in 2-year-old normal and risk infants. Pediatrics, 59 (suppl.): 982 (1977).

244. We wish to acknowledge the administrative assistance of Dr. Eric Elliot, of the General Clinical Research Centers Branch, the Division of Research Resources, National Institutes of Health and the editorial assistance of Ms. Annette Terzian.

245. Reprint requests to ERS, Department of Pediatrics, UCLA Medical Center. Los Angeles, CA 90024

246. Received for publication March 1, 1983.

247. Accepted for publication May 11, 1983

\title{
The Effect of Small but Sustained Elevations in Circulating Growth Hormone on Fuel Metabolism in Growth Hormone Deficiency
}

\author{
WILLIAM V. TAMBORLANE. ${ }^{(13)}$ MYRON GENEL, STEPHANIE GIANFREDI. AND \\ JOSEPH M. GERTNER \\ Section of Pediatric Endocrinology, Department of Pediatrics, Yale University School of Medicine, \\ New Haven, Connecticul. USA
}

\section{Summary}

Although growth hormone $(\mathrm{GH})$ concentrations are not always pathologically elevated in patients with acromegaly, it has been suggested that the metabolic and somatic consequences of this condition may be due to a loss of the normal episodic secretion of GH. To examine the effects of maintaining modest but constant levels of circulating GH, we administered continuous subcutaneous infusions of growth hormone (CSIGH) to eight previously untreated GH-deficient children (6-19 yr).

CSIGH given for $90 \mathrm{~h}$ in doses equivalent to the standard dose for replacement therapy, raised mean serum GH levels from less than 3.0 to $5.9 \pm 1.0 \mathrm{ng} / \mathrm{ml}$. In comparison, 24-h mean GH levels in five normal adolescents averaged $10.1 \pm 1.5 \mathrm{ng} / \mathrm{ml}$. As expected, however, normals showed much more variability in GH concentration. The constant elevations in serum GH levels achieved with CSIGH produced significant impairment of oral glucose tolerance. During CSIGH, plasma glucose concentrations $60-120 \mathrm{~min}$ after oral glucose loading were $30-40 \mathrm{mg} / \mathrm{dl}$ higher than corresponding pre-infusion values $(P<0.01)$. This impairment of oral glucose tolerance during CSIGH occurred despite a doubling of the area under the insulin/time curve after oral glucose $(P<0.02$ versus pre-infusion area). Indeed, plasma insulin levels after oral glucose in patients on CSIGH exceeded those observed in normal controls, suggesting that CSIGH had induced a degree of insulin resistance.

There was a transient increase in plasma free fatty acid levels on the first day of CSIGH. Somatomedin-C concentration remained unchanged in four of six patients. We conclude that small but sustained increases in growth hormone concentrations in GH deficiency can, when infused continuously, have effects on fuel metabolism similar to those observed during pathologic GH hypersecretion.

\section{Abbreviations}

CSIGH, continuous subcutaneous infusions of growth hormone FFA, free fatty acids

GH, growth hormone

GH-secreting pituitary adenomas are characterized clinically by excessive somatic growth and hyperinsulinemia with or without glucose intolerance. In a recent study of patients with such adenomas, however. Clemmons et al. (3) demonstrated that the manifestations of acromegaly were not closely dependent on serum GH levels. Indeed, in certain individuals increased heel pad thickness and hyperglycemia were observed despite basal GH levels that lay within the normal range. 